Review

\title{
Recent Advances on Carbon Nanotubes and Graphene Reinforced Ceramics Nanocomposites
}

\author{
Iftikhar Ahmad ${ }^{1}$, Bahareh Yazdani ${ }^{2}$ and Yanqiu Zhu ${ }^{2, *}$ \\ 1 Center of Excellence for Research in Engineering Materials, Advanced Manufacturing Institute, \\ King Saud University, Riyadh 11421, Saudi Arabia; E-Mail: ifahmad@ksu.edu.sa \\ 2 College of Engineering, Mathematics and Physical Sciences, University of Exeter, \\ Exeter EX4 4QF, UK; E-Mail: by219@exeter.ac.uk \\ * Author to whom correspondence should be addressed; E-Mail: y.zhu@exeter.ac.uk; \\ Tel.: +44-139-272-3620.
}

Academic Editor: Emanuel Ionescu

Received: 9 December 2014 / Accepted: 12 January 2015 / Published: 20 January 2015

\begin{abstract}
Ceramics suffer the curse of extreme brittleness and demand new design philosophies and novel concepts of manufacturing to overcome such intrinsic drawbacks, in order to take advantage of most of their excellent properties. This has been one of the foremost challenges for ceramic material experts. Tailoring the ceramics structures at nanometre level has been a leading research frontier; whilst upgrading via reinforcing ceramic matrices with nanomaterials including the latest carbon nanotubes (CNTs) and graphene has now become an eminent practice for advanced applications. Most recently, several new strategies have indeed improved the properties of the ceramics/CNT nanocomposites, such as by tuning with dopants, new dispersions routes and modified sintering methods. The utilisation of graphene in ceramic nanocomposites, either as a solo reinforcement or as a hybrid with CNTs, is the newest development. This article will summarise the recent advances, key difficulties and potential applications of the ceramics nanocomposites reinforced with CNTs and graphene.
\end{abstract}

Keywords: nanocomposites; mechanical properties, interface; graphene; carbon nanotubes (CNTs); ceramics 


\section{Introduction}

Ceramics are potential contestants for diverse sophisticated engineering applications, and plenty of attentions have been focused to further improve their properties by adopting emerging technologies. As a result, much deeper understandings and significant amounts of improvements in their structures and properties have been achieved after decades of efforts. However, many challenge issues limit their wide applications, such as the degradation of high temperature mechanical properties of non-oxide silicon nitride $\left(\mathrm{Si}_{3} \mathrm{~N}_{4}\right)$ and silicon carbide $(\mathrm{SiC})$, and low fracture toughness, poor creep, deprived thermal shock resistance of oxide ceramics like alumina $\left(\mathrm{Al}_{2} \mathrm{O}_{3}\right)$ and zirconium oxide $\left(\mathrm{ZrO}_{2}\right)$ [1]. To date, ceramics have found some niche applications, from high speed cutting tools, dental implants, chemical and electrical insulators, to wear resistance parts and various coatings, due to their high hardness, chemical inertness and high electrical and thermal insulating properties [2]. Low fracture toughness restricts ceramics for applications in aircraft engine parts and in extreme environments for space engineering [3]. Presence of impurities, pores and cracks cause pure ceramics extremely brittle, and complex/expensive processing technology is needed to reduce such fatal drawbacks. For decades, the addition of a second reinforcing phase in ceramics has been an effective practice to improve their toughness, converting brittle ceramics to practical engineering materials. Recent advances in nanomaterials have offered the opportunity to tailor the ceramic structures at nanometre scale, for the development of new classes of stronger, tougher engineering ceramics with added functionalities. Chosen nanomaterials with distinct morphologies and properties have been used to reinforce monolithic ceramics [4-6]. In particular, the exceptional mechanical behaviour and outstanding multifunctional features of carbon nanotubes (CNTs) and graphene have made them the wonder materials, standing out from many other nanomaterials, among different research communities. There has been much documented research attempting to incorporate both types of CNT in brittle ceramics to convert them into tough, strong, electric and thermal conductive materials [7-15]. Graphene, known as a monolayer of carbon atoms arranged in a honeycomb lattice, has shown similar properties to carbon nanotubes with impressive thermal, mechanical, and electrical properties, and is a promising alternative of CNTs in various applications [16-18]. Compared with CNTs, graphene also have large specific surface areas and they do not form agglomerates in a matrix when handled appropriately, thus an ideal nano-filler for composite materials. In this regard, the low-cost, high quality and commercially more viable a-few-layer-thick graphene nanosheets, designated as graphene nanoplatelets (GNPs) are more promising for practical engineering applications, thus attracted considerable research interests for advanced ceramic matrices. Indeed, various crucial ceramics such as $\mathrm{Al}_{2} \mathrm{O}_{3}, \mathrm{Si}_{3} \mathrm{~N}_{4}$ and $\mathrm{ZrO}_{2}$ have been reinforced by the GNP fillers and obvious improvements in fracture toughness, thermal and electrical properties have been obtained [19-26]. However, research of ceramic-GNP nanocomposites is in its infancy, and more thorough and systematic studies are required.

Nevertheless, ceramics reinforced with CNTs, graphene and GNT (CNTs/graphene hybrid) have indeed showed significant improvements in the fracture toughness and other mechanical properties by following complex toughening mechanisms, although wide variations in the results still remain problematic. In fact, processing ceramic nanocomposites is complicated due to the introduction of a second reinforcement phase of nanometric scale. Conventional rules and benefits associated with microscopic reinforcement phases need to be modified carefully and validated fully before being 
applied directly. In this context, recent advances in the fabrication technology, mechanical properties and potential applications of typical ceramic nanocomposites reinforced with CNTs and graphene are presented in this paper. The main purpose of this review is to provide a comprehensive picture of the current state of research progresses and challenges concerning the graphene and CNTs-reinforced ceramic composites, to assist the ceramic community for further developments.

\section{CNTs-Reinforced Ceramics Nanocomposites}

\subsection{Pre-Processing for Good Dispersion}

A statistical summary of the varieties of processes opted to fabricate CNTs containing ceramic nanocomposites is graphically presented in Figure 1, and Table 1 gives further details of these processes. It is evident that $88 \%$ of the reported cases used the readily available and economically feasible multi-walled carbon nanotubes (MWCNTs) as the reinforcement, against single-walled carbon nanotubes (SWCNTs). Nearly 40\% adopted a wet oxidation process (treatment with concentrated $\mathrm{H}_{2} \mathrm{SO}_{4}$ and $\mathrm{HNO}_{3}$ in 3:1 ratio) to purify the CNTs in an effort to remove unwanted impurities including amorphous carbon nanofibres, carbon nanoparticles, amorphous carbon coating layers, and metallic catalyst residues; and about $33 \%$ of the reports attempted pristine CNTs; whilst the others tried oxidation through annealing [27-30]. The wet oxidation purification method for CNTs offers two folded advantages, realizing purification and simultaneous attachments of carboxyl functional groups onto the CNT surfaces which facilitates their mixing with and dispersions into matrices. It is a fact that CNT clusters prevent each individual CNT forming the ideal interconnection desired with the matrix, leading to ill-constructed interface and microstructures, detrimental to the final mechanical properties. Thus homogenous CNT dispersion within the matrix is extremely imperative. In addition, the actual quality of CNT dispersion is the foremost factor in tumbling the densities of CNT-reinforced ceramics, because homogenous dispersion is attainable only at low CNT concentrations $(<2 \mathrm{wt} \%)$, and higher than that normally ended up with severe agglomerations [31].

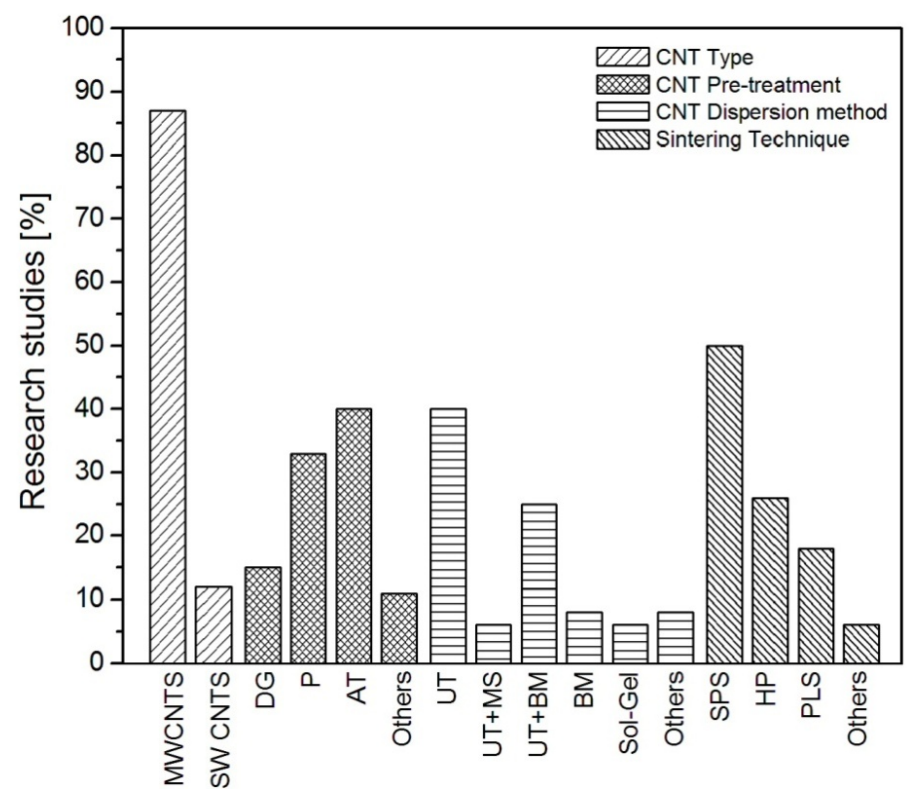

Figure 1. Statistical analysis of the carbon nanotubes (CNTs)-reinforced ceramic nanocomposites. 
Table 1. Processing details of CNTs-reinforced ceramics nanocomposites.

\begin{tabular}{|c|c|c|c|c|c|}
\hline Reference & Matrix & $\begin{array}{l}\text { CNT } \\
\text { types }\end{array}$ & $\begin{array}{l}\text { Purification } \\
\text { methods }\end{array}$ & Dispersion procedures & Sintering techniques \\
\hline$[10]$ & $\mathrm{Si}_{3} \mathrm{~N}_{4}$ & SW & $\mathrm{P}$ & $\begin{array}{l}\text { UT of CNTs with surfactant } \\
(\mathrm{C} 16 \mathrm{TAB}) \text { and } \mathrm{Si}_{3} \mathrm{~N}_{4}\end{array}$ & SPS under vacuum \\
\hline$[12]$ & $\mathrm{Al}_{2} \mathrm{O}_{3}$ & MW & $\begin{array}{l}\text { Oxidation at } 500{ }^{\circ} \mathrm{C} \\
\text { for } 90 \mathrm{~min}\end{array}$ & UT of CNTs in ethanol & $\begin{array}{l}\mathrm{SPS} \text { at } 1500^{\circ} \mathrm{C} \text { for } \\
10 \text { min under } 50 \mathrm{MPa}\end{array}$ \\
\hline$[32]$ & $\mathrm{Al}_{2} \mathrm{O}_{3}$ & MW & $\mathrm{AT}\left(\mathrm{H}_{2} \mathrm{SO}_{4}+\mathrm{HNO}_{3}\right)$ & $\begin{array}{l}\text { UT of CNTs into water and } \\
\text { SDS then incubation for } \\
2 \text { weeks }\end{array}$ & $\begin{array}{l}\mathrm{HP} \text { at } 1600^{\circ} \mathrm{C}, 60 \mathrm{~min} \text {, } \\
40 \mathrm{MPa}\end{array}$ \\
\hline$[33]$ & $\mathrm{Al}_{2} \mathrm{O}_{3}$ & MW & $\begin{array}{l}\text { AT }\left(\mathrm{H}_{2} \mathrm{SO}_{4}+\mathrm{HNO}_{3}\right) \\
\text { for } 3 \mathrm{~h}\end{array}$ & $\begin{array}{l}24 \mathrm{~h} \mathrm{BM} \text { of ball } \mathrm{Al}_{2} \mathrm{O}_{3} \text { powder } \\
\text { and } 30 \text { min } \mathrm{UT} \text { of CNTs in } \\
\text { water and then } \mathrm{BM} \text { of } \\
\mathrm{CNTs} / \mathrm{Al}_{2} \mathrm{O}_{3} \text { mixture }\end{array}$ & $\begin{array}{l}\text { PLS at } 1500-1600{ }^{\circ} \mathrm{C}, \\
120-240 \mathrm{~min}, \mathrm{Ar}\end{array}$ \\
\hline$[34]$ & $\mathrm{Al}_{2} \mathrm{O}_{3}$ & MW & Pristine & UT of CNTs for $1 \mathrm{~h}$ in alcohol & $\begin{array}{l}\mathrm{CIP} \text { at } 150 \mathrm{MPa} \text { and } \\
\text { PLS at } 1500^{\circ} \mathrm{C} \text {, and } \\
1700^{\circ} \mathrm{C} \text { with } 2 \mathrm{~h}\end{array}$ \\
\hline$[35]$ & $\mathrm{Al}_{2} \mathrm{O}_{3}$ & MW & $\begin{array}{l}\mathrm{AT} \text { (heating in } 65 \% \\
\mathrm{HNO}_{3} \text { at } 80^{\circ} \mathrm{C} \text { for } \\
8 \mathrm{~h} \text { ) }\end{array}$ & $\begin{array}{l}\text { BM and Surfactant (Darvan } \\
\mathrm{C}-\mathrm{N})\end{array}$ & $\begin{array}{l}\text { PLS at } 1500^{\circ} \mathrm{C} \text { for } 2 \mathrm{~h} \\
\text { using } \mathrm{Ar}\end{array}$ \\
\hline$[36]$ & Mulite & MW & $\mathrm{P}$ & $\begin{array}{l}\text { CNTs dispersion into ethanol by } \\
\text { MS and UT }\end{array}$ & $\begin{array}{l}\mathrm{HP} \text { at } 1600^{\circ} \mathrm{C} \text { for } \\
60 \text { min under } \mathrm{Ar} \\
\text { atmosphere at } 30 \mathrm{MPa}\end{array}$ \\
\hline$[37]$ & $\mathrm{Si}_{3} \mathrm{~N}_{4}$ & MW & $\mathrm{P}$ & $\begin{array}{l}24 \mathrm{~h} \text { ball milling the CNTs and } \\
\mathrm{Si}_{3} \mathrm{~N}_{4} \text { slurry }\end{array}$ & $\begin{array}{l}\mathrm{HP} \text { at } 1750{ }^{\circ} \mathrm{C} \text { for } \\
60 \text { min under } 30 \mathrm{MPa}\end{array}$ \\
\hline$[38]$ & $\mathrm{ZrB}_{2}-\mathrm{SiC}$ & MW & $\mathrm{P}$ & $\begin{array}{l}20 \text { min UT of CNTs and matrix } \\
\text { with subsequent } 24 \mathrm{~h} \\
\text { ball milling }\end{array}$ & $\begin{array}{l}\mathrm{HP} \text { at } 1900^{\circ} \mathrm{C} \text { for } \\
60 \text { min under } 30 \mathrm{MPa}\end{array}$ \\
\hline [39] & $\mathrm{BaTiO}_{3}$ & MW & $\mathrm{P}$ & - & $\mathrm{HP}, 1200^{\circ} \mathrm{C}, 60 \mathrm{~min}$ \\
\hline$[40]$ & $\mathrm{Al}_{2} \mathrm{O}_{3}$ & MW & - & $\begin{array}{l}\mathrm{DG}\left(\mathrm{CVD} \text { at } 750{ }^{\circ} \mathrm{C} \text { for } 15 \mathrm{~min}\right. \\
\text { for direct } \mathrm{CNTs} \text { growth on } \\
\mathrm{Al}_{2} \mathrm{O}_{3} \text { nano-particles) }\end{array}$ & $\begin{array}{l}\text { SPS at } 1150^{\circ} \mathrm{C} \text { for } \\
10 \text { min under } 100 \mathrm{MPa}\end{array}$ \\
\hline [41] & $\mathrm{Al}_{2} \mathrm{O}_{3}$ & SW & Pristine & UT of CNTs in ethanol & $\begin{array}{l}\text { SPS at } 1520^{\circ} \mathrm{C} \text { under } \\
80 \mathrm{MPa}\end{array}$ \\
\hline$[42]$ & $\mathrm{Al}_{2} \mathrm{O}_{3}$ & MW & $\mathrm{P}$ & $35 \mathrm{~h} \mathrm{UT}$ in water & $\begin{array}{l}\text { SPS at } 1300{ }^{\circ} \mathrm{C}, \\
20 \mathrm{~min}, 90 \mathrm{MPa}\end{array}$ \\
\hline$[43]$ & $\mathrm{Al}_{2} \mathrm{O}_{3}$ & MW & $\mathrm{AT}$ & $\begin{array}{l}\mathrm{UT} \text { of } \mathrm{CNTs} \text { and } \mathrm{Al}_{2} \mathrm{O}_{3} \text { in water } \\
\text { followed by } 2 \mathrm{~h} \text { and } \mathrm{BM} \\
\text { of } \mathrm{CNTs} / \mathrm{Al}_{2} \mathrm{O}_{3}\end{array}$ & $\begin{array}{l}\text { PLS at } 1600{ }^{\circ} \mathrm{C}, \\
15 \mathrm{~min}, \mathrm{Ar}\end{array}$ \\
\hline [44] & $\mathrm{Al}_{2} \mathrm{O}_{3}$ & MW & $\begin{array}{l}\mathrm{AT}\left(\mathrm{HNO}_{3} \text { for }\right. \\
30 \mathrm{~min})\end{array}$ & $\begin{array}{l}5 \mathrm{~h} \text { BM of CNTs and } 1 \mathrm{~h} \mathrm{UT} \text { of } \\
\text { CNTs. } 5 \mathrm{~h} \mathrm{BM} \text { of } \mathrm{CNT} / \mathrm{Al}_{2} \mathrm{O}_{3} \\
\text { in ethanol }\end{array}$ & PLS at $1550{ }^{\circ} \mathrm{C}, \mathrm{Ar}$ \\
\hline
\end{tabular}


Table 1. Cont.

\begin{tabular}{|c|c|c|c|c|c|}
\hline Reference & Matrix & $\begin{array}{l}\text { CNT } \\
\text { types }\end{array}$ & $\begin{array}{l}\text { Purification } \\
\text { methods }\end{array}$ & Dispersion procedures & Sintering techniques \\
\hline [45] & $\mathrm{Al}_{2} \mathrm{O}_{3}$ & MW & $\begin{array}{l}\mathrm{AT}\left(\mathrm{H}_{2} \mathrm{SO}_{4}+\mathrm{HNO}_{3}\right. \\
\text { in } 3: 1 \text { for } 7 \mathrm{~h})\end{array}$ & $\begin{array}{l}\text { surfactant (SDS) using } \\
\text { combination of UT and } \\
24 \mathrm{~h} \mathrm{BM}\end{array}$ & $\begin{array}{l}\mathrm{HP} \text { at } 1550{ }^{\circ} \mathrm{C} \text { for } 1 \mathrm{~h} \\
\text { under } 30 \mathrm{MPa} \text { using } \\
\text { Ar gas }\end{array}$ \\
\hline [46] & $\begin{array}{l}\mathrm{Al}_{2} \mathrm{O}_{3}+ \\
\mathrm{ZrO}\end{array}$ & MW & $\begin{array}{l}\text { AT (heating in } 65 \% \\
\text { HNO3 at } 80{ }^{\circ} \mathrm{C} \text { for } \\
8 \mathrm{~h}) \text { ) }\end{array}$ & $\begin{array}{l}2 \text { min UT of CNTs with } \\
\text { surfactant (SDS)and } 24 \text { BM } \\
\text { then freezing with Nitrogen }\end{array}$ & $\begin{array}{l}\mathrm{HP} \text { at } 1500^{\circ} \mathrm{C} \text { for } 2 \mathrm{~h} \\
\text { under } 30 \mathrm{MPa} \text { in } \\
\text { Ar atmosphere }\end{array}$ \\
\hline [47] & $\mathrm{Al}_{2} \mathrm{O}_{3}$ & SW & $\begin{array}{l}\mathrm{AT}\left(\mathrm{H}_{2} \mathrm{SO}_{4}+\right. \\
\left.\mathrm{HNO}_{3}\right)\end{array}$ & $\mathrm{UT}$ for $24 \mathrm{~h}$ & $\begin{array}{l}\text { SPS at } 1300^{\circ} \mathrm{C} \text { for } \\
5 \mathrm{~min} \text { under } 75 \mathrm{MPa}\end{array}$ \\
\hline
\end{tabular}

Notes: SW: Single-walled CNTs; MW: Multi-walled CNTs; UT: Ultrasonication; BM: Ball milling; HP: Hot-pressing; SPS: Spark plasma sintering; PLS: Pressureless sintering; SDS: Sodium dodecyle sulphate; CIP: cold isostatic pressing; P: Pristine; MS: Magnetic stirring.

To combat this dispersion issue, as shown in Figure 1, the most dominant (40\%) technique involving colloidal technology (ultra-sonication of CNTs for different durations into different solvents with or without surfactants). Until recently, attempts increasingly focused on a combined process (colloidal technique and ball milling) which have produced better results and was more reproducible than other techniques (ball milling, sol-gel, planetary centrifuge mixing, magnetic stirring, tape casting, etc.), as shown in Table 1. Moreover cationic, anionic and neutral surfactants have greatly contributed to the detangling of CNT clusters, of which SDS (sodium dodcyle sulphate) seems to be the most used one [11]. In addition, several reports described the growth of CNTs directly onto the surface of ceramics nanoparticles using a standard chemical vapour deposition (CVD) technique; however, this method failed to create high quality coverage, on top of the low yield issues [13].

Cultivation of CNTs in porous ceramics is intriguing process, and numerous efforts have been documented for highly ordered $\mathrm{CNT}$ growth within the pores of thin $\mathrm{SiO}_{2}$ and $\mathrm{Al}_{2} \mathrm{O}_{3}$ membranes, which led to novel CNTs-reinforced porous ceramics with potential applications as field emitters, nanocapacitors, and scanning microscope probes [48-52]. To prepare CNTs carrying porous ceramic composites, Fan et al. [27] first embedded catalyst inside the $\mathrm{SiO}_{2}$ pores of the ceramics pores, then allowed for the carbon source to diffuse into and deposit inside the pores; whilst Kyotani et al. [48] grew CNTs on an anodic aluminium oxide (AAO) porous membrane with and without catalyst. The CNT growth mechanism in a catalyst free CNTs-porous ceramic is still not completely understood. The AAO membrane template may itself catalysed the CNT growth by deposition of carbon atoms on the internal pore surface of the complex three dimensional structure, as proposed by Sui et al. [49]. Since catalyst facilities carbon source decomposition, thus further deposition of atomic carbon tends to result in more ordered or well-crystallised structures, leading to better quality nanocomposites than the non-catalysed process. Patterning and lithography technology enabled Bae et al. to deposit a thin Si layer on an AAO substrate for enhanced CNT growth [50]. Parham et al. have recently prepared a $3 \mathrm{wt} \%$ CNT-containing composite using $\mathrm{Al}_{2} \mathrm{O}_{3}$ and $\mathrm{SiO}_{2}$ porous ceramics, and resulting composites exhibited a high efficiency for yeast cell filtration (98\%), a 100\% heavy metal ions removal from water and excellent particulate filtration performance from air $[51,52]$. 
Despite these achievements for CNT dispersion in various ceramic matrices, some known issues still remain. For example, SWCNTs are always produced in the form of bundles of tens of nanotubes, and their separation into individual tubes is still extremely difficult, concerning the nanocomposite fabrication. This area thus needs further investigations, because SWCNTs have promising applications in biomedical engineering, composite technology and nanodevices [30]. Dispersion of CNTs within ceramic matrices is generally assessed by the microscopic images of the fractured surfaces of nanocomposite samples taken from desired areas of interest, and the representativeness of this method sometimes is a concern, as it may not be a true reflection of the CNT dispersions for other locations [53-55]. Therefore, the standardization of CNT dispersion assessments in composites beyond ceramics is vital for quality control in manufacturing and industrial applications.

\subsection{Densification Processes}

Achieving near full density, without damaging the CNT structure and morphology, is a fundamental requirement and another important challenge in ceramic matrix nanocomposite technology, as most of the mechanical properties are strongly affected by the density. CNTs hinder the ceramic grains coalescence by existing at the grain boundaries, which tends to lead to poorly densified microstructures [56]. For this reason, pressure-assisted consolidification processes are generally be used to counter this problem. Figure 1 shows that about $76 \%$ nanocomposites were consolidated by pressure-assisted sintering processes, in which spark plasma sintering (SPS) and hot-pressing (HP) have a share of 50\% and 26\%, respectively. Hot-pressing provides simultaneous high pressures and high temperatures to powder systems, which in turn gives high densities, thus good mechanical properties to either pure ceramics and their composites. Coble et al. explained that the enhanced densities were associated with accelerate densification due to higher stresses caused by external pressure, and this phenomenon consolidated the grains to a desirable density; unfortunately, damage to the CNTs during the matrix grain growth could occur due to prolong sintering at extremely high temperatures which was a potential big shortcoming of HP [32,57]. The structural damage problem of CNTs during HP can be avoided by using SPS technique, in which near full densification is achievable at lower sintering temperatures with substantially short holding time. The microscopic images (Figure 2) showed that the CNTs were mainly located at the ceramic grain boundaries, well adhered with the matrix without apparent damage to the structure and morphology [58]. Pressureless sintering (PLS) offers convenient and cheaper consolidation alternations, but wide variation in earlier results have made this technique unattractive and debatable. For example, Zhan et al. [15] and Ahmad et al. [59] claimed widely different densities for similar samples, as high as $99 \%$ and as low as $<90 \%$ for $1 \mathrm{wt} \%$ CNTs-reinforced $\mathrm{Al}_{2} \mathrm{O}_{3}$, respectively. However in recent reports, Sarkar et al. [34] densified $\mathrm{Al}_{2} \mathrm{O}_{3}$ containing 0.3 vol\% of MWCNTs to $>99 \%$ at $1700{ }^{\circ} \mathrm{C}$ using PLS sintering; and similarly Michalek et al. [35] and Ghobadi et al. [60] obtained $99.9 \%$ and $>98 \%$ densities for $\mathrm{Al}_{2} \mathrm{O}_{3}$ reinforced with $0.1 \mathrm{wt} \%$ and 1 vol\% MWCNTs, respectively. Regarding other ceramics, Tatami et al. [61] achieved $\mathrm{Si}_{3} \mathrm{~N}_{4}-\mathrm{MWCNTs}$ composites by pressureless sintering during which the constituents including sintering additives were initially pressed uniaxially and subsequently sintered in furnace at $1700{ }^{\circ} \mathrm{C}$ under $\mathrm{N}_{2}$ atmosphere. They recorded a drop in relative densities from $100 \%$ to $90 \%$ for 0 to $5 \mathrm{wt} \%$ CNT additions; whilst they obtained much higher densities $>96 \%$ for $5 \mathrm{wt} \%$ MWCNT additions by using HP. Microwave sintering 
is another inspiring and "green" sintering technique, with the advantage of lower densification temperatures and shortened processing time. This technique has been successfully used to consolidate most mainstream industrial ceramics (e.g., $\mathrm{Al}_{2} \mathrm{O}_{3}, \mathrm{ZrO}_{2}, \mathrm{Si}_{3} \mathrm{~N}_{4}$ ), both pure and composite forms, and resulted in high densities, due to rapid microwaves heating characteristics [62,63]. Nevertheless, the mixed large and fine grained microstructure of the final ceramic consolidated by microwave sintering has made it bit divisive, but this technique exhibits great potentials for CNTs-reinforced ceramics' densification. The advantageous features such as short sintering time and low densification temperatures are not deleterious for CNT structures; furthermore the localize heating at the grain boundaries may be helpful in constructing strong interfaces between CNTs and the ceramic matrices; finally, the grain coarsening seems not a big issue in microwave sintered CNTs-reinforced ceramics, possibly owing to the grain refining tendency of CNTs $[64,65]$. Table 1 covers the HP, PLS and SPS these main methods.
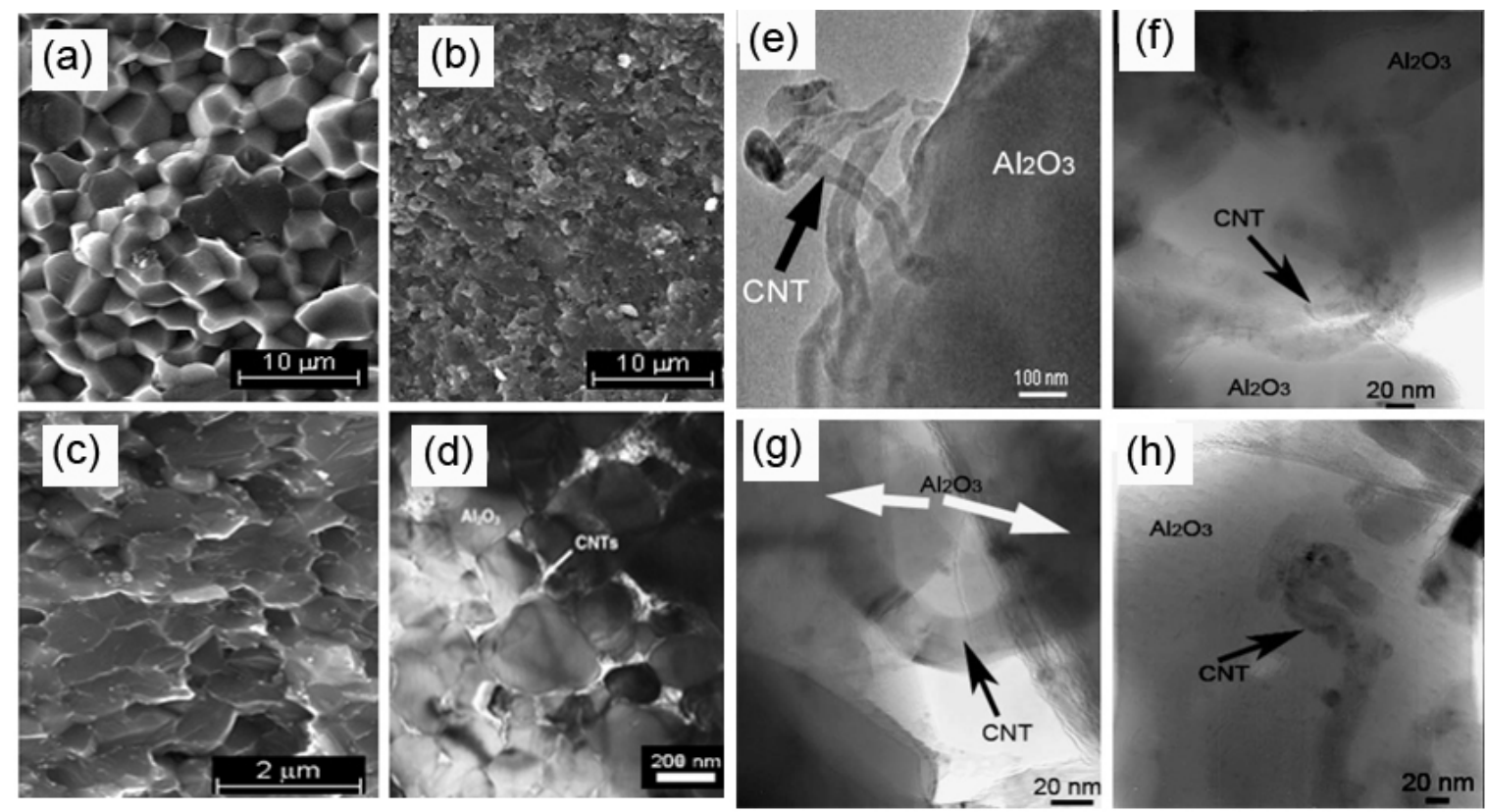

Figure 2. Structural features of (a) Monolithic $\mathrm{Al}_{2} \mathrm{O}_{3}$ showing large grains with inter-granular fracture; (b) $\mathrm{CNTs} / \mathrm{Al}_{2} \mathrm{O}_{3}$ nanocomposites with fine grains; (c) Trans-granular fracture mode in $\mathrm{CNTs} / \mathrm{Al}_{2} \mathrm{O}_{3}$ nanocomposites; and (d) Single-walled (SW)CNTs at grain boundary of $\mathrm{Al}_{2} \mathrm{O}_{3}$ matrix. TEM images exhibiting the CNT-ceramic interactions (e) Multi-walled (MW)CNTs (black arrow) showing their morphology in nanocomposite; (f) A single MWCNT existing at grain boundary; (g) in porosity and (h) Embedded within a single ceramic grain. Adapted from References [32] and [66] with permissions. Copyright 2010, Elsevier Ltd.

In seeking of highly dense composite structure, new techniques are always attempted, and we will summarise a few diverse and interesting methods here. For example, in order to protect the CNT structures by preventing reactions with SiC during high temperature integration, Thostenson et al. first prepared a preform of SiC nanoparticles and CNTs (duly dispersed in polymer matrix) then carbonized the perform followed by infiltrating molten Si into the preform under vacuum at $1400{ }^{\circ} \mathrm{C}$ to claim dense nanocomposites; whilst Wang et al. packed SiC nanoparticles and CNTs in a cylinder and 
arranged graphite heater inside the cylinder followed by heating up to $1700{ }^{\circ} \mathrm{C}$ to consolidate the CNTs-SiC mixture [36,67-69].

\subsection{Microstructural Analysis}

Sharp reduction from coarser grains in monolithic ceramics (Figure 2a) to finer grains in CNTs-reinforced ceramics (Figure 2b) is a principle feature of structural change, occurred due to the pinning of matrix grains by CNTs which restricted the grain growth during sintering [66]. Fracture mode alteration from inter-granular in monolithic ceramics (Figure 2a) to trans-granular in the CNTs-reinforced ceramics (Figure 2c) is another interesting change being revealed. The morphological analyses of fractured surfaces are helpful in depicting the mechanisms behind such changes. In the case of monolithic $\mathrm{Al}_{2} \mathrm{O}_{3}$, it shows clearly the edge and corner fractural features (Figure 2a), representing the typical inter-granular fracture mode; and conversely a blurry and glaze-like surface appears for CNTs-reinforced $\mathrm{Al}_{2} \mathrm{O}_{3}$ (Figure 2c), indicating the trans-granular mode of fracture [66]. These observations mean that CNTs, as the second phase, must be responsible for altering the fracture modes. Indeed, when CNTs were homogenously dispersed within the ceramic matrix, they arranged themselves at various locations such as along grain boundaries (Figure 2f), across grains boundaries (Figure $2 \mathrm{~g}$ ), inside single grains (Figure $2 \mathrm{~h}$ ), contributing to strengthening the composites at nanometre level by making bridges across grains and sharing the grains, as discussed in prior studies [66,70]. Presumably, all these interesting arrangements of CNTs in ceramic matrices promoted the trans-granular fracture, rather than inter-granular fracture as did in the pure ceramic. In a very recent report, Ahmad et al. obtained 5-fold finer grain size in $\mathrm{MWCNTs} / \mathrm{Al}_{2} \mathrm{O}_{3}$ nanocomposites by $300 \mathrm{ppm} \mathrm{Y}_{2} \mathrm{O}_{3}$ doping than its undoped $\mathrm{Al}_{2} \mathrm{O}_{3}$ counterpart, and mixed inter/intra fracture mode in $\mathrm{Y}_{2} \mathrm{O}_{3}$ doped nanocomposites was observed [31,37]. However this fracture mode change phenomenon is another grey area that is not fully understood for CNTs-reinforced ceramics, which offers opportunities for prospective thinking and further research work.

\subsection{Mechanical and Functional Properties}

In view of the vast applications of the economically viable $\mathrm{Al}_{2} \mathrm{O}_{3}$ ceramics in industry, lots of studies have been done to improve their fracture toughness by CNT additions. However, inconsistent results (Table 2) put question marks on these triumphs and core issues in such discrepancies were found in the CNT dispersion methods, choice of sintering process and techniques adopted for characterisation $[34,40,41,50,59,61,71,72]$. For example, Table 2 shows that the higher fracture toughness values of MWCNTs-reinforced $\mathrm{Al}_{2} \mathrm{O}_{3}$ were obtained at lower CNT additions $(<2 \mathrm{wt} \%)$, and declining trend can be seen at higher CNT levels in all cases, except from the values reported by Zhan et al. [15]. Furthermore, the composite fracture toughness reported by Zhan et al. [15] was the highest in Table 2. However, this value may be due to various factors: (1) the use of SPS techniques (positive); (2) reinforcement phase being SWCNTs (positive); and (3) the assessment of the fracture toughness by an unreliable direct crack method, DCM, (negative). Yamamoto et al. [12] used the SPS to sinter similar composite reinforced with MWCNTs, and used the single-edged notched beam (SENB) method to assess the fractures toughness, however the results were now as good as the results reported by Zhan et al. [15] and Ahmad et al. [31]. In case of the high values reported by Ahmad et al. [66], it 
is probably due to the better dispersion of CNTs within the matrix, as they adopted a unique method. Further, Huang et al. [39] showed tremendous improvements in fracture toughness $(57 \%, 114 \%$ and $328 \%$ ) values for $\mathrm{BaTiO}_{3}$ ceramic after reinforced with $(0.5,1$ and $3 \mathrm{wt} \%$ ) MWCNTs; whereas a $15 \%$ improvement was recorded by Tian et al. [38] for $2 \mathrm{wt} \%$ MWCNTs-reinforced $\mathrm{ZrB} 2-\mathrm{SiC}$ ceramics.

Table 2. Properties of CNTs-reinforced ceramics.

\begin{tabular}{|c|c|c|c|c|c|c|}
\hline Reference & Matrix & CNT contents & $\begin{array}{c}\text { Relative } \\
\text { density (\%) }\end{array}$ & $\begin{array}{c}\text { Hardness } \\
\text { (GPa) }\end{array}$ & $\begin{array}{c}\text { Flexural } \\
\text { strength } \\
(\mathrm{MPa})\end{array}$ & $\begin{array}{c}\text { Fracture } \\
\text { toughness } \\
\left(\text { MPa. }^{1 / 2}\right)\end{array}$ \\
\hline \multirow{2}{*}[10]{} & \multirow{2}{*}{$\mathrm{Si}_{3} \mathrm{~N}_{4}$} & 0 & 99.2 & 15.7 & 1046 & 4.8 \\
\hline & & $1 \mathrm{wt} \% \mathrm{MWCNTs}$ & 98.7 & 15.0 & 996 & 6.6 \\
\hline \multirow{3}{*}[12]{} & \multirow{3}{*}{$\mathrm{Al}_{2} \mathrm{O}_{3}$} & 0 & 95.6 & 17.3 & 500 & 4.4 \\
\hline & & $0.5 \mathrm{wt} \% \mathrm{MWCNTs}$ & 99.2 & 16.8 & 685 & 5.9 \\
\hline & & $1 \mathrm{wt} \%$ MWCNTs & 98.9 & 15.9 & 650 & 5.7 \\
\hline \multirow{2}{*}{ [15] } & \multirow{2}{*}{$\mathrm{Al}_{2} \mathrm{O}_{3}$} & 0 & - & - & - & 3.3 \\
\hline & & $3 \mathrm{wt} \%$ SWCNTs & - & - & - & 7.9 \\
\hline \multirow{2}{*}{ [27] } & \multirow{2}{*}{$\mathrm{Al}_{2} \mathrm{O}_{3}$} & 0 & 97.7 & - & 326 & 3.08 \\
\hline & & $6 \mathrm{wt} \% \mathrm{MWCNTs}$ & 95.4 & - & 314 & 5.55 \\
\hline \multirow{3}{*}[32]{} & \multirow{3}{*}{$\mathrm{Al}_{2} \mathrm{O}_{3}$} & 0 & 99.8 & 16 & 356 & 3.5 \\
\hline & & $2 \mathrm{wt} \%$ MWCNTs & 99.5 & 18 & 402 & 6.8 \\
\hline & & $5 \mathrm{wt} \%$ MWCNTs & 99.1 & - & 423 & 5.7 \\
\hline \multirow{2}{*}{ [34] } & \multirow{2}{*}{$\mathrm{Al}_{2} \mathrm{O}_{3}$} & 0 & 99.5 & 17.5 & 222 & 3.92 \\
\hline & & 0.15 vol $\%$ MWCNTs & 98.4 & 21.4 & 242 & 5.27 \\
\hline \multirow{2}{*}{ [35] } & \multirow{2}{*}{$\mathrm{Al}_{2} \mathrm{O}_{3}$} & 0 & - & 16.9 & - & 5.5 \\
\hline & & 1 vol $\%$ MWCNTs & - & 13.5 & - & 6.0 \\
\hline \multirow[b]{2}{*}[36]{} & \multirow{2}{*}{$\begin{array}{c}\text { Mulite } \\
\left(3 \mathrm{Al}_{2} \mathrm{O}_{3}\right. \\
\left.+2 \mathrm{SiO}_{2}\right) \\
\end{array}$} & 0 & - & - & 466 & 2.0 \\
\hline & & $2 \mathrm{wt} \% \mathrm{MWCNTs}$ & - & - & 512 & 3.3 \\
\hline \multirow{2}{*}[69]{} & \multirow{2}{*}{$\mathrm{SiC}$} & 0 & 939 & - & 303 & 3.3 \\
\hline & & $10 \mathrm{wt} \%$ MWCNTs & 94.7 & - & 321 & 3.8 \\
\hline \multirow{2}{*}[38]{} & \multirow{2}{*}{$\mathrm{ZrB}_{2}-\mathrm{SiC}$} & 0 & - & 15.8 & 582 & 4 \\
\hline & & $2 \mathrm{wt} \%$ MWCNTs & - & 15.5 & 616 & 4.6 \\
\hline \multirow{5}{*}{ [39] } & \multirow{5}{*}{$\mathrm{BaTiO}_{3}$} & 0 & 98.5 & & & 0.7 \\
\hline & & 98.50 & 98.5 & & & 0.7 \\
\hline & & $0.5 \mathrm{wt} \%$ MWCNTs & 97.3 & - & - & 1.1 \\
\hline & & $1 \mathrm{wt} \%$ MWCNTs & 99.2 & & & 1.5 \\
\hline & & $3 \mathrm{wt} \%$ MWCNTs & 98.6 & & & 3.0 \\
\hline \multirow{2}{*}{ [73] } & \multirow{2}{*}{$\mathrm{Al}_{2} \mathrm{O}_{3}$} & 0 & - & - & 395 & 4.41 \\
\hline & & 20 vol $\%$ MWCNTs & - & - & 403 & 4.62 \\
\hline \multirow{2}{*}{ [74] } & \multirow{2}{*}{$\mathrm{Al}_{2} \mathrm{O}_{3}$} & 0 & - & - & - & 3 \\
\hline & & $1 \mathrm{wt} \%$ MWCNTs & - & - & - & 5 \\
\hline \multirow{2}{*}[75]{} & & 0 & - & 15.71 & - & 3.24 \\
\hline & $\mathrm{Al}_{2} \mathrm{O}_{3}$ & $5 \mathrm{wt} \%$ MWCNTs & - & 0.72 & - & 4.14 \\
\hline & & 0 & - & 18.2 & - & 4.5 \\
\hline [76] & $\mathrm{Al}_{2} \mathrm{O}_{3}$ & $2.5 \mathrm{wt} \% \mathrm{MWCNTs}$ & - & 15.75 & - & 11.4 \\
\hline & & 0 & 99.9 & 22.9 & - & 3.54 \\
\hline [77] & $\mathrm{Al}_{2} \mathrm{O}_{3}$ & 10 vol $\%$ MWCNTs & 97.4 & 11 & - & 2.76 \\
\hline
\end{tabular}


Recently, Sarkar et al. [34] calculated fracture toughness values of the $\mathrm{Al}_{2} \mathrm{O}_{3}-\mathrm{MWCNT}$ nanocomposites by employing DCM method using Niihara and Liang models, and reported better fracture toughness values than those obtained using SENB technique; whereas Ahmad et al. [66], reported higher fracture toughness values attained from SENB method than those obtained from DCM method using Chantikul model. These conflicting reports suggest that engineering components cannot be validated for structural load-bearing applications using DCM method; however, this convenient method is widely employed for fracture toughness comparisons [31]. Similar inconclusive and controversial fracture toughness values regarding CNTs-reinforced $\mathrm{Si}_{3} \mathrm{~N}_{4}$ were also reported by Corral et al. [10] and Pasupuleti et al. [37] Both consolidate $\mathrm{Si}_{3} \mathrm{~N}_{4}$ with $1 \mathrm{wt} \%$ CNTs and obtained 30\% reduction (by SENB method) and 40\% increment (by ISB method) in fracture toughness, respectively.

Regarding other mechanical properties such as hardness and elastic modulus, Yamamoto et al. [12] investigated a range of MWCNT additions in $\mathrm{Al}_{2} \mathrm{O}_{3}$ ceramics and concluded a drop in hardness and rise in flexural strengths at low MWCNT additions and further reduction in both properties by adding more MWCNTs, and consistent results were reported by many others for the same material system, as shown in Table 2. Pasupuleti et al. [37] showed a small decrease in hardness (4\%) and flexural strength $(5 \%)$ for $1 \mathrm{wt} \%$ MWCNTs-reinforced $\mathrm{Si}_{3} \mathrm{~N}_{4}$, however, Corral et al. [10] reported a much severer $45 \%$ reduction in hardness for same reinforcement contents in $\mathrm{Si}_{3} \mathrm{~N}_{4}$.

The dual role of CNTs, indirectly enhancing the mechanical properties and directly acting as lubricant, converts ceramic composites into an attractive wear resistance material, and various reports demonstrated the steady reduction of friction coefficient with CNT additions [78]. High thermal and electrical properties of the CNTs have been predicted and several attempted to incorporate CNTs into insulated ceramics in order convert them into highly electrical and thermally conductive materials [73]. Ceramics exhibited higher electric conductivity (EC) when reinforced with SWCNTs $\left(10^{6} \mathrm{~S} / \mathrm{m}\right)$ than with MWCNTs $\left(10^{3}-10^{5} \mathrm{~S} / \mathrm{m}\right)$ [40,79]. Sarkar et al. reported that the EC of MWCNTs-reinforced composites was dependent on the formation of electrically conductive networks by dispersing the CNTs homogenously in the matrix, and on the grain sizes of the final nanocomposites, as larger grain size with less grain boundaries showed better results [80]. So far Estili et al. has obtained the highest EC of $4816 \mathrm{~S} / \mathrm{m}$ for $\mathrm{Al}_{2} \mathrm{O}_{3}-20$ vol\% MWCNTs, which is $43 \%$ higher than that reported by Zhan et al. [73,79]. In addition, Kumari et al. obtained an exceptional value of $3336 \mathrm{~S} / \mathrm{m}$ by reinforcing $\mathrm{Al}_{2} \mathrm{O}_{3}$ with $19 \mathrm{wt} \%$ MWCNTs nanocomposites, however, at the cost of poor mechanical properties [41]. In contrast to MWCNTs, the SWCNTs reinforcement into the $\mathrm{Al}_{2} \mathrm{O}_{3}$ matrix offered better conductivity of $3345 \mathrm{~S} / \mathrm{m}$ without compromising mechanical properties [71]. Zaman et al. studied the effects of surface functionalization of the SWCNTs on EC and reported that the hydroxyl group functionalized SWCNT offered $\sim 10$ times higher EC in 1 wt $\%$ SWCNTs-reinforced $\mathrm{Al}_{2} \mathrm{O}_{3}$ nanocomposites than those functionalized by carboxylic acid group [72]. Moreover, Bi et al. reported a drop in the electrical percolation by increasing the aspect ratios of MWCNTs [81]. Although the thermal conductivity (TC) of SWCNTs and MWCNTs are ranges from 3000 to $6000 \mathrm{~W} / \mathrm{m} \cdot \mathrm{K}$, however, their nanocomposite with ceramics barely demonstrated good thermal performance. Compared to unreinforced $\mathrm{Al}_{2} \mathrm{O}_{3}$, Zhan et al. reported lower $(7.3 \mathrm{~W} / \mathrm{m} \cdot \mathrm{K})$ TC in nanocomposites reinforced with $15 \mathrm{vol} \%$ SWCNTs than their monolithic counterpart $(27.3 \mathrm{~W} / \mathrm{m} \cdot \mathrm{K})$ [71]. Both Kumari et al. and Bakshi et al. reported higher TC values $(63.52$ and $6 \mathrm{~W} / \mathrm{m} \cdot \mathrm{K})$ in nanocomposites 
with ( 8 and $4 \mathrm{wt} \%$ ) MWCNTs than those of pure $\mathrm{Al}_{2} \mathrm{O}_{3}(19.96$ and $5.37 \mathrm{~W} / \mathrm{m} \cdot \mathrm{K})$ samples, respectively [82]. This area of research is therefore more complicated and interesting.

\subsection{CNTs/Ceramic Interface and the Toughening Mechanism}

Reinforcement (fibres or whiskers) pullout is the main toughening mechanism in conventional ceramics, which is further associated with weak interfacial connection of reinforcement with matrix. Same classical approach was proposed for toughness mechanism in CNTs-reinforced ceramics in several initial reports [83-85]. However, in later research Padture et al. and many others observed that micro-structural features of CNTs-ceramics were immensely dissimilar from conventional composites, and these observations strongly suggested that existing microscale mechanism may not be fully applicable to CNTs-ceramic systems [18,23,61]. Microstructure of conventional ceramic composites consists of inflexible and straight reinforcement, and the interface is optimally designed in such a way that it debonds on applied load [86]. Imagine, when a reinforcement encounters a crack then it bridges the crack in its wake, pullout does frictional work and these together effectively make crack propagation more difficult, in addition to this large reinforcement dimensions lead to longer crack-wake bridging zones and consequently resulted in higher toughness [85,87]. Meanwhile, these large reinforcements prompt larger flaws and turn strength to lower values. In contrast, CNTs are highly flexible, hollow nanometre sized fibres, therefore the toughening mechanism may be entirely different from conventional ones. Frictional pullout of fibres occurred in classical composites may not be the only toughening mechanism in CNTs-reinforced ceramics. Accordingly, new concepts and philosophies of uncoiling and elastic stretching of CNTs during the crack propagation were proposed as main toughness mechanisms by Padture et al. [7]. During crack propagation, initial uncoiling of CNTs occurs in the crack wake, and when the crack further propagates the uncoiled CNT stretches elastically serving as stretched CNT bridges instead of conventional frictional pull-out bridges, thus impedes the crack propagation, as shown in Figure $2 \mathrm{~g}$ [66]. These concepts are convincingly identified the role of CNTs as an individual entity, also applied to the cluster form. Surface damages to SWCNTs during purification and subsequent sintering process are well-known, and in this picture the role of CNT's elastic stretching in toughness is slightly litigious. In this regard, mathematical modelling will be a helpful tool in explaining the role of CNTs in strengthening ceramics and predicting their behaviour in services.

Recent developments in the electron microscope technology are changing the research approaches, and attentions are now tending to focus on tailoring the interface structure at atomic level, to construct defect-free structures with interesting functionalities. FIB-SEM (focused ion beam scanning electron microscopy) has made the scientists' life not as hard as ages ago. A TEM (transmission electron microscope) sample of hard materials, e.g., ceramics can be prepared in hours, which was a laborious task to arrange for days and even weeks earlier. For $\mathrm{CNTs}-\mathrm{Al}_{2} \mathrm{O}_{3}$ nanocomposites, due to the interesting reaction of $\mathrm{Al}_{2} \mathrm{O}_{3}$ with alkaline, a simple powder etching process can always be used to collect CNTs with a thin layer of $\mathrm{Al}_{2} \mathrm{O}_{3}$ residue, for interface study under TEM. Similar results are obtained when compared with FIB-SEM [66].

Back to CNTs-reinforced ceramics, where the interface controls the CNT debonding, pullout and crack-bridging at micron and nanometre level, these different mechanisms act as energy dissipative 
processes during mechanical loading. Physically, an interface is a complex transitional region layered between the reinforcement and parent matrix thus, the control of interface chemistry and tailoring smart microstructures are essential steps for producing exceptionally tough and strong nanocomposites. Dedicated efforts have been done to explore the CNTs-ceramic transition region and each addressed in interesting way $[12,66]$. Indeed, rough surface of CNTs produces the required frictional forces which resist in detaching CNTs from the ceramic matrix. Yamamoto et al. proposed that acid treatment does not significantly damage the overall structures of MWCNTs however, localized etches of the cylindrical body at different locations create nanoscale defects (nano-pits) along the tube axis, as shown in Figure 3b [12]. These nano-pits having depths of $\sim 15 \mathrm{~nm}$ are anchored by the matrix grains (Figure 3c), forming locks and resistance in MWCNTs' sliding over the matrix, thus leading to good connection of composite constituents at the interface [12]. Further, a close cross-sectional look of the MWCNT shown in Figure 3d of the high resolution TEM image reveals its uneven surface, hollow core and graphitic layers. These layers are not concentrical on a long distance and many compartments exist, which is a typical feature of MWCNTs synthesized by CVD. Ahmad et al. [78] postulated that high surface roughness of the CNTs could result in two potential advantages like chemically highly reactive and physically difficult to slide out of the matrix, compared with a smooth surface. The former could help to improve the interfacial bonding with the matrix and the latter can pose much larger friction forces to stop the CNT pullout [78].
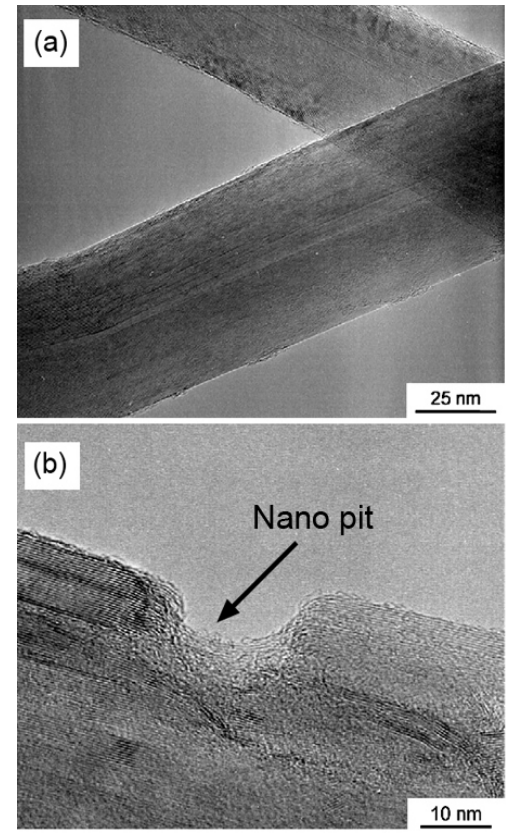
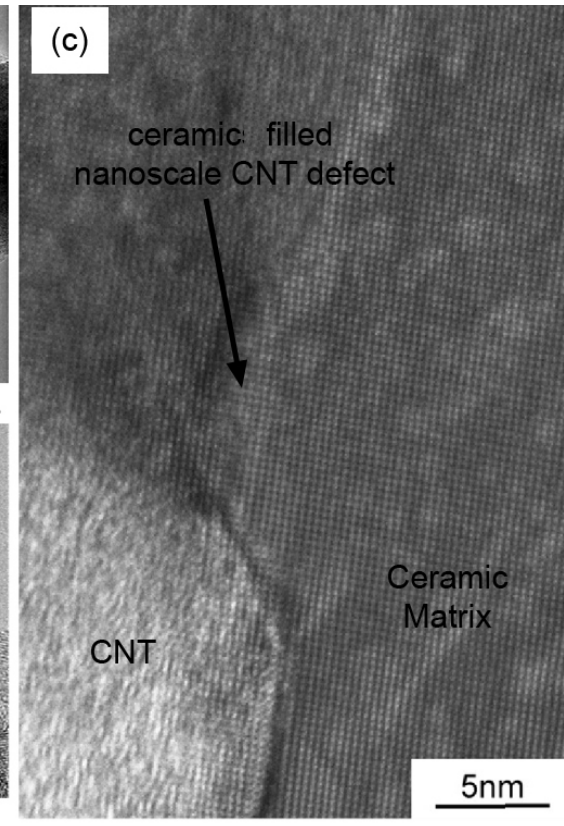

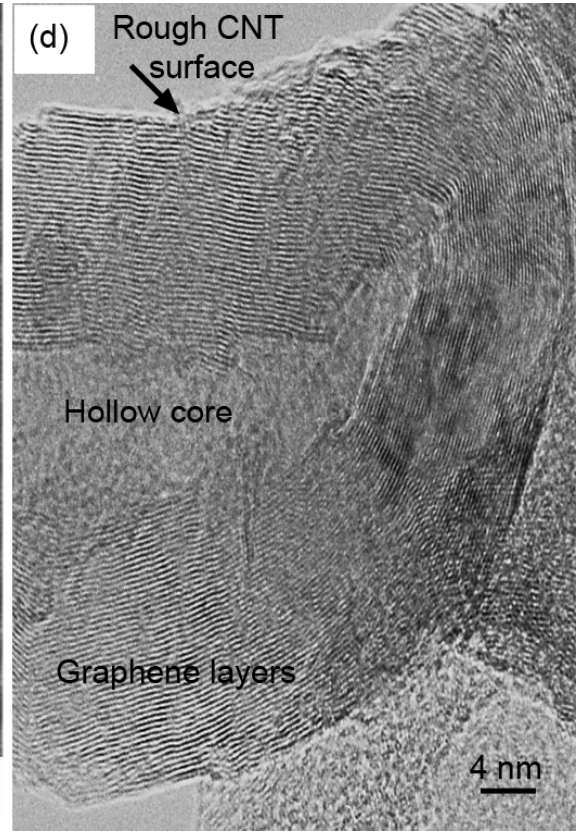

Figure 3. (a) TEM image of the pristine MWCNTs; (b) High-magnification TEM image of the acid-treated MWCNT surface, arrow indicates nano-pit; (c) Nano-pit on the acid-treated MWCNTs is filled up with $\mathrm{Al}_{2} \mathrm{O}_{3}$ crystal; and (d) Rough surface of MWCNT produced by chemical vapour deposition (CVD) method. Adapted from References [12] and [32] with permissions. Copyright 2009, Elsevier Ltd. and 2008 IOP Publishing Ltd.

The CNT's surface unevenness and its anchoring with the ceramics matrix are a good physical explanation of enhanced frictional forces at the interface. However, the chemical interactions of CNTs 
with the ceramics remained unattended for several years. Estili et al. [88] rigorously studied the interfacial areas of $\mathrm{CNTs} / \mathrm{Al}_{2} \mathrm{O}_{3}$ nanocomposites using high resolution-TEM, but unable to identify any interfacial phases or intermediate compounds at the $\mathrm{CNTs} / \mathrm{Al}_{2} \mathrm{O}_{3}$ interface. A recent attempt addressed this topic and explained the chemical activity took place at the $\mathrm{CNTs} / \mathrm{Al}_{2} \mathrm{O}_{3}$ interface during $\mathrm{HP}$ process, and reported the formation of an extremely thin (1-2 nm) intermediate phase of $\mathrm{Al}_{2} \mathrm{OC}$, which is possibly produced due to the carbothermal reduction of $\mathrm{Al}_{2} \mathrm{O}_{3}$ by CNTs [78]. Figure $4 \mathrm{a}-\mathrm{b}$ show clear evidence of a CNT sticking with $\mathrm{Al}_{2} \mathrm{O}_{3}$ at the interface.

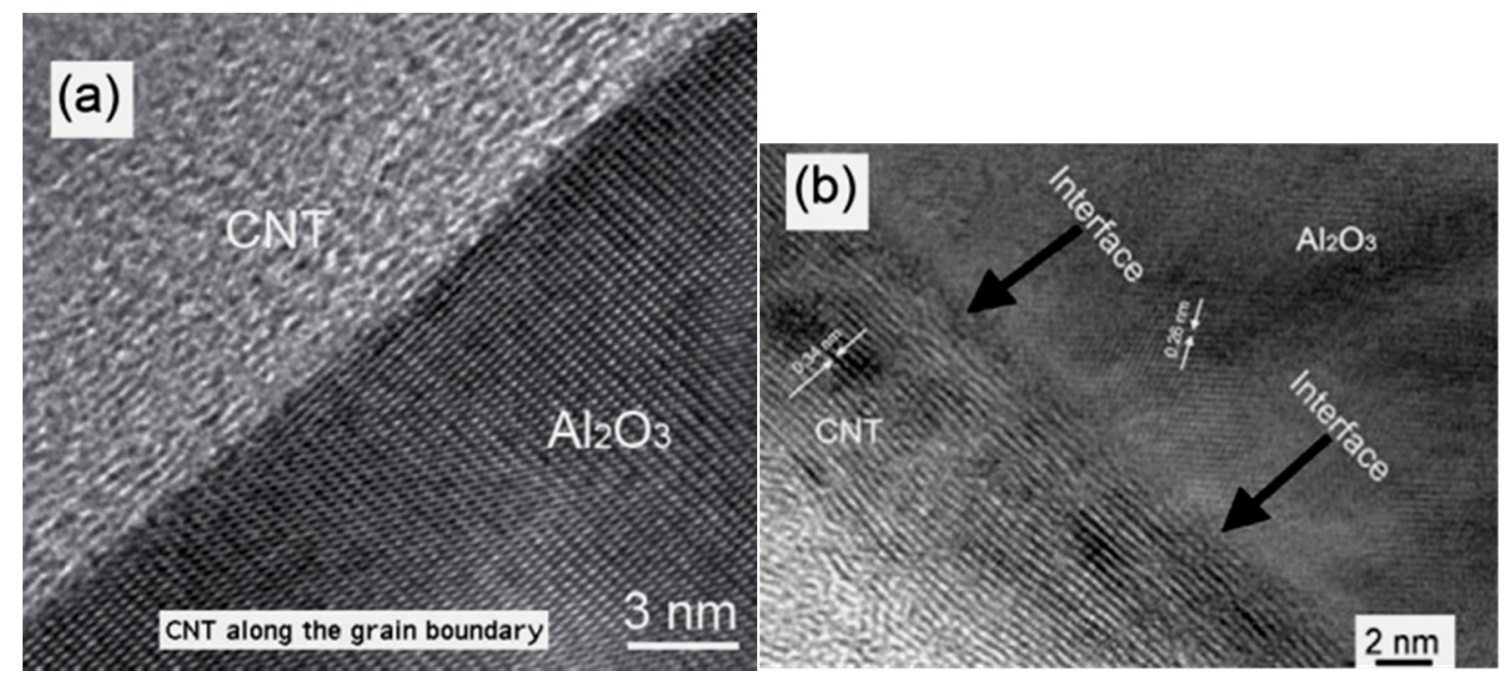

Figure 4. (a,b) High-resolution TEM images showing CNT/ceramic interfaces. Adapted from References [15] and [32] with permissions. Copyright 2005 Advanced Study Center Co. Ltd. and 2010 Elsevier Ltd.

Owning to the multi-layer graphene structure of MWCNTs, the possibility of such chemical and physical reactions with the accommodation of nano-pits and eating of few outer layers for $\mathrm{Al}_{2} \mathrm{OC}$ or $\mathrm{Al}_{4} \mathrm{C}_{3}$ formation can be justified. However, this may not be true for SWCNTs which contain only a single graphene layer while forming the tubular structure, even plenty of studies claimed tremendous improvements in ceramics properties $[22,26]$. This raises one big question as to being only one layer how it reacts with the matrix to form a good interface following the toughening mechanisms proposed above. Therefore, this mystery remains unresolved. The understanding of the nanostructure characteristics and the interfacial relationship between SWCNTs and the ceramic matrices is far from satisfactory, which opens new windows of potential research in this advanced area of nanotechnology $[18,26,40,61]$.

\section{Graphene Reinforced Ceramic Nanocomposites}

\subsection{Raw Materials}

As a cousin of CNTs, the 2D graphene bears many similarities to CNTs in terms of nanocomposites application. For bulk engineering nanocomposite applications which require large volume amount, a few layered graphene platelets or flakes, including the reduced graphene oxide (GO), are far more viable and economical than single layered graphene. Therefore, the term graphene in this context refers to graphene nanoplatelets (GNPs). 
In composite applications, both the mechanical exfoliation and reduction from GO have been used successfully [89-94]. In the mechanical cleavage method, commercial graphite powder (Aldrich) has been milled intensively in high efficient attritor mill in the presence of ethanol for $10 \mathrm{~h}$, then the produced GNPs were mixed with ceramic powder [89]. The second method uses the Hummers' process to produce GO, then using this water soluble GO to mix with ceramic powders [90]. In general, both mechanical milling and hummers method suffers from various sizes and thicknesses for the former due to lack of control on the milling energy and from surface structural damage for the latter originated from the oxidation [91], which will have negative effects on the final properties of the ceramic composites. Therefore, better quality control of the GNPs is of fundamentally importance for high quality nanocomposites development.

\subsection{GNS Dispersions Processes}

As discussed above for CNTs, mixing step is an equally challenging step in preparing graphene-reinforced ceramics composites. To avoid any damage and reduce agglomeration of GNPs will help to achieve high mechanical and physical properties. In essence, the dispersion of GNPs in fact is easier than CNTs, as the difficulties accompanied in CNT's dispersion such as high aspect ratio and van der Waals interactions which cause CNT bundling are absence for GNPs. In addition, high specific area and 2D geometry of GNPs offer better disperseability in ceramic matrices. As a younger cousin to CNTs, the gained knowledge for CNTs can generally be used as a reference for GNPs-reinforced ceramic composites. Thus in this context, focus will be mainly on the different features with comparison.

Wet powder mixing are successful to disperse CNTs in ceramic matrixes [92-95], whilst for GNPs the choice of solvents are much wider than processing CNTs. Isopropyl alcohol NMP, DMF have all be used to mix with various ceramic matrices such as $\mathrm{Al}_{2} \mathrm{O}_{3}, \mathrm{Si}_{3} \mathrm{~N}_{4}$, and $\mathrm{ZrO}_{2}$ powders. This drawback of this technique is energy consuming, and might cause damage to the GNP reinforcements. Colloid processing is a modified wet mixing process, and the key is to produce stabilized suspensions from GNTs and ceramic particles by changing their surface chemistry which facilitates homogeneous dispersion of GNPs. Anionic or cationic surfactants are generally used to alter the surface charge of GNPs, to positive or negative respectively, followed by adding them to a ceramic suspension with the same/opposite charges to form an homogenous ceramic-GNP dispersion. This hetero-coagulation process is a very effective route for well-dispersed ceramic composites [12,91]. Starting with GO, Wang et al. [20] used such electrostatic attractions between $\mathrm{GO}$ and $\mathrm{Al}_{2} \mathrm{O}_{3}$ particles to obtain homogenous dispersions of $\mathrm{GO}$ in $\mathrm{Al}_{2} \mathrm{O}_{3}$ powder first, followed by subsequent reduction of $\mathrm{GO}$, who achieved a 53\% and 13 orders of magnitude improvement in fracture toughness and conductivity. Walker et al. [25] used CTAB in both the GNPs and $\mathrm{Si}_{3} \mathrm{~N}_{4}$ suspensions for mixing, and resulted in a $235 \%$ improvement in fracture toughness with only 1.5 vol $\%$ GNP addition.

\subsection{Sintering Techniques}

The densification of GNPs-reinforced ceramic nanocomposites also includes pressureless sintering, HP, SPS and HIP (hot-isostic pressing). The low temperature requirement and fast sintering rate advantages of SPS made it widely used for ceramic nanocomposites filled with carbon 
nano-fillers [20,24,43,95-98]. However, there are a few groups reported very good GNPs-reinforced ceramic nanocomposites based on HP densification [97-100]. For example, the GNPs-Si3N4 nanocomposites reported by Rutkowski et al. [99] showed improved thermal properties. After comparing the HP and SPS processes for GNPs- $\mathrm{Al}_{2} \mathrm{O}_{3}$ nanocomposites, Inam et al. [98] found out that the structural integrity of graphene from HP process is better than SPSed samples, with higher crystallinity, thermal stability and electrical conductivity, and was attributed to the thermally induced graphitization caused by longer sintering condition in a HP.

\subsection{Structural Features, Mechanical Properties and Toughening Mechanisms}

Toughening ceramic is one of the main research objectives for GNP nanocomposites, whist other benefits such as flexural strength and hardness can also be obtained. Using only $1.5 \mathrm{vol} \%$ the flexible 2D GNPs as a reinforcement for $\mathrm{Si}_{3} \mathrm{~N}_{4}$, Walker et al. reported a 235\% improvement in the toughness, and found GNPs anchoring with or wrapping around $\mathrm{Si}_{3} \mathrm{~N}_{4}$ grains [25], thus blocking the crack propagation through the GNPs. This is the first time that such toughening mechanism was observed, and is a major different from the 1D CNTs. The same effective anchoring toughening was also confirmed by Liu et al. [24] in their GNPs $/ \mathrm{Al}_{2} \mathrm{O}_{3}$ system, documented a $30.75 \%$ increase in flexural strength and a $27.20 \%$ increase in fracture toughness. These securely anchored GNPs around $\mathrm{Al}_{2} \mathrm{O}_{3}$ grains can form large area of interfaces with the matrix, increasing the interfacial friction, therefore the energy required for pulling out GNPs from the matrix will be greater than pulling out CNTs. They also successfully extended their process to a GNPs-reinforcing the $\mathrm{ZrO}_{2}-\mathrm{Al}_{2} \mathrm{O}_{3}$ system using SPS [24], in comparison with CNTs. The authors believed that due to similar mechanical properties to CNTs, and better dispersability GNPs are an effective alternative for CNTs in ceramic composites. In $\mathrm{Si}_{3} \mathrm{~N}_{4}$ matrix, Tapaszto et al. [100] showed that GNPs indeed outperformed CNTs. However, it should be noted that, due to the larger contact area between GNPs and the matrix grains, the interface quality plays a more important role in toughening the ceramics than CNTs and other reinforcement phases.

The different roles of CNTs and GNPs separately in ceramic matrices were well-documented, however within the same matrix could be more complex. A combination of the various advantages of different reinforcement phases, the very nature of the composite concept, could lead to superior properties, however this has rarely been investigated so far in ceramics. Very recently, Yazdani et al. [26] reported both $63 \%$ and $17 \%$ improvements in fracture toughness and flexural strength by using such a hybrid (MWCNTs + GNPs $=$ GNTs) reinforcement phase in $\mathrm{Al}_{2} \mathrm{O}_{3}$ matrix. In their report, the role of GNPs and CNTs has been investigated separately. As evident in Figure 5, a large GNP rolled around $\mathrm{Al}_{2} \mathrm{O}_{3}$ grain due to its flexibility and produced large area of interface with $\mathrm{Al}_{2} \mathrm{O}_{3}$ matrix; therefore, it increased the required pull out energy during fracture and strengthened the grain boundaries so the fracture occurred through the $\mathrm{Al}_{2} \mathrm{O}_{3}$ grains rather than along the grain boundaries, whist MWCNTs contributed more to the bridging effect due to their higher aspect ratio. It is believed that MWCNTs can be stretched much longer than GNPs before collapsing during crack propagation. These roles are complementary with each other at appropriate concentrations, allowing for absorbing more energy during crack propagations. 


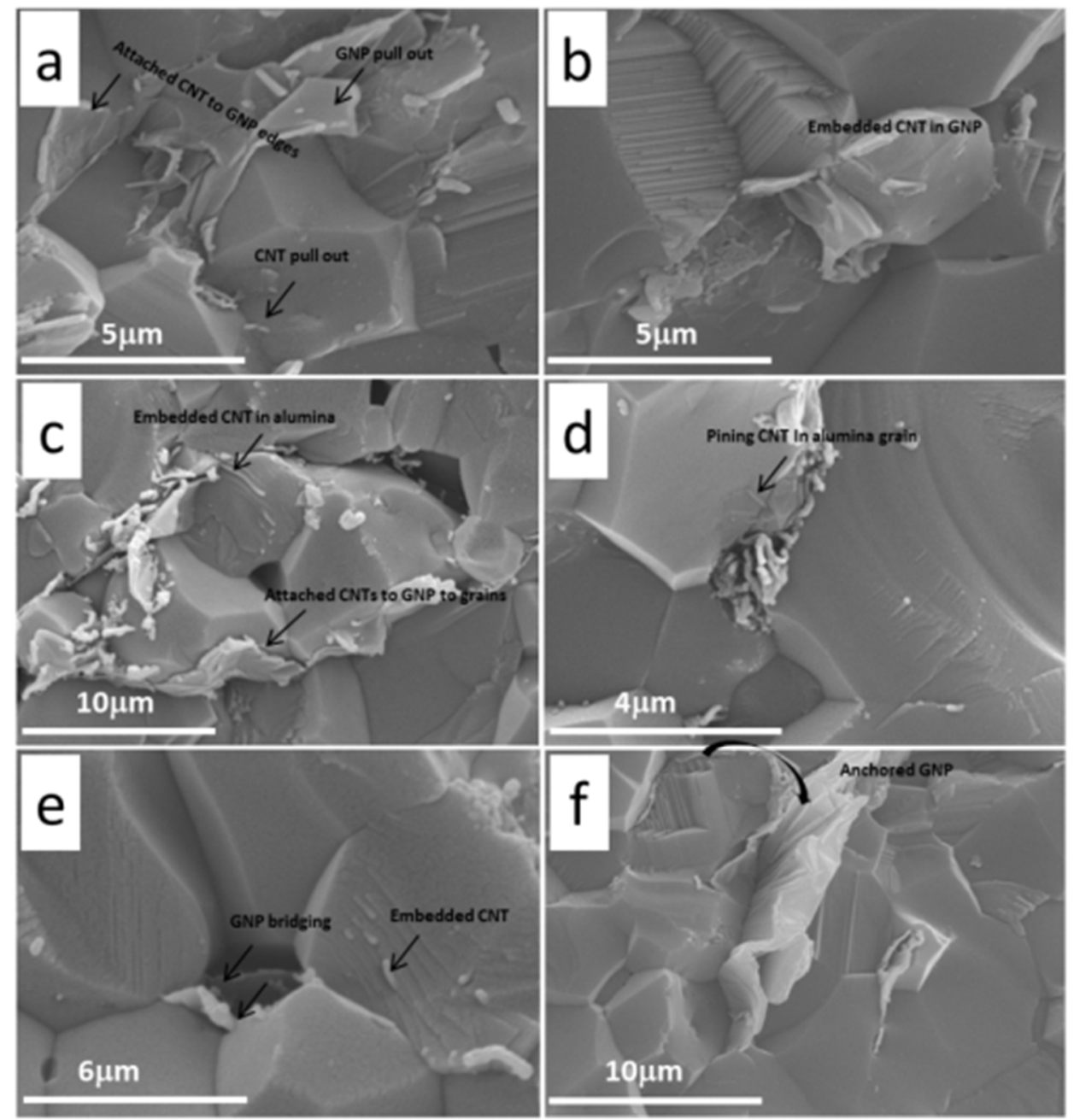

Figure 5. SEM images from fractured surface of $\mathrm{GNT}_{-} \mathrm{Al}_{2} \mathrm{O}_{3}$ nanocomposites with various GNP/CNT ratio, (a and b); $\mathrm{Al}_{2} \mathrm{O}_{3}-(0.5 \mathrm{wt} \% \mathrm{GNP}+1 \mathrm{wt} \% \mathrm{CNT}),(\mathbf{c}-\mathbf{e}) ; \mathrm{Al}_{2} \mathrm{O}_{3}-(0.5 \mathrm{wt} \%$ $\mathrm{GNP}+0.5 \mathrm{wt} \% \mathrm{CNT}),(\mathbf{f}) ; \mathrm{Al}_{2} \mathrm{O}_{3}-0.5 \mathrm{wt} \%$ GNP. Adapted from Reference [26] with permission. Copyright 2014 Elsevier Ltd.

\section{Potential Applications}

Owing to the improved fracture toughness and ancillary benefits of electrical and thermal properties, ceramics reinforced with CNTs and GNPs are promising for numerous prospective applications in the field of photonics, biomedical, automotive and aerospace engineering. Firstly, associated with the enhanced mechanical performance of $\mathrm{Al}_{2} \mathrm{O}_{3}$, the significantly improved wear resistance property of these composites could be suitable for a number of wear and sliding applications in automobile industry like cylinder lines, valve seat and piston rings [101]. Secondly, the $\mathrm{SiC}_{2} \mathrm{Si}_{3} \mathrm{~N}_{4}$ and $\mathrm{BaTiO}_{3}$ systems filled with CNTs made them suitable for structural applications, such as bearings, seals, armour, liners, nozzles and cutting tools. Thirdly, the thermally and chemically stable ceramic composites could revise their high thermal conductivity and be suitable for high temperature components such as in jet engine and brake disks for aircrafts [102]. Further, CNTs/GNPs can also convert ceramics into functional materials for aerospace and automobile industries, such as knock sensors, seat pressure sensors, temperature sensors, oil sensors, impact sensors and road surface 
sensors, whilst the outstanding electrical properties of $\mathrm{CNTs} / \mathrm{GNPs}$ make $\mathrm{Al}_{2} \mathrm{O}_{3}$ ceramic attractive for specific applications like heating elements, electrical igniters, electromagnetic/antistatic shielding of electronic components, electrode for fuel cells, crucibles for vacuum induction furnaces and electrical feed through $[44,74,86,103-105]$. Table 3 summarises the potential industries may have benefits from ceramic nanocomposites reinforced with CNTs and graphene. As the research is progressing in this important area, novel CNTs-reinforced ceramics with stunning properties are expected and may substituted several automobile and aerospace components in future furthermore, owning functionalities these have potential for third generation nanodevices.

Table 3. Potential application of key ceramics nanocomposites reinforced with CNTs and graphene.

\begin{tabular}{|c|c|c|c|c|c|}
\hline References & $\begin{array}{l}\text { Ceramic } \\
\text { matrix }\end{array}$ & $\begin{array}{l}\text { Reinforcing } \\
\text { agent }\end{array}$ & Key properties & Parts/Components & Potential industries \\
\hline$[101]$ & $\mathrm{Al}_{2} \mathrm{O}_{3}$ & CNTs/graphene & $\begin{array}{l}\text { Wear resistance, } \\
\text { high toughness, } \\
\text { electrical properties, } \\
\text { thermal properties }\end{array}$ & $\begin{array}{l}\text { Cutting tools, } \\
\text { corrosion/erosion } \\
\text { resistance pipes, } \\
\text { electrical contacts, } \\
\text { armour plates }\end{array}$ & $\begin{array}{l}\text { Automobile, } \\
\text { petrochemical industry, } \\
\text { electric component } \\
\text { manufacturing, defence } \\
\text { industry }\end{array}$ \\
\hline [106] & $\mathrm{Si}_{3} \mathrm{~N}_{4}$ & CNTs/graphene & $\begin{array}{l}\text { Excellent } \\
\text { mechanical, } \\
\text { chemical, and } \\
\text { thermal properties }\end{array}$ & $\begin{array}{l}\text { Gas turbines, } \\
\text { aircraft engine } \\
\text { components and } \\
\text { bearings }\end{array}$ & $\begin{array}{l}\text { Power generation, } \\
\text { aerospace, automobile } \\
\text { sector }\end{array}$ \\
\hline [107] & $\mathrm{BaTiO}_{3}$ & CNTs/graphene & $\begin{array}{l}\text { Ferroelectrics, } \\
\text { piezoelectric and } \\
\text { colossal } \\
\text { magnetoresistor } \\
\text { properties }\end{array}$ & $\begin{array}{l}\text { Electric generator, } \\
\text { computer hard } \\
\text { disks, sensors }\end{array}$ & $\begin{array}{l}\text { Renewable energy, } \\
\text { power generation, } \\
\text { electronic, computer } \\
\text { manufacturing, data } \\
\text { storage, aerospace } \\
\text { industry }\end{array}$ \\
\hline [108-110] & $\mathrm{ZrO}_{2}$ & CNTs/graphene & $\begin{array}{l}\text { High mechanical } \\
\text { properties, excellent } \\
\text { fracture toughness, } \\
\text { elevated temperature } \\
\text { stability, high } \\
\text { breakdown electrical } \\
\text { field and large } \\
\text { energy bandgap }\end{array}$ & $\begin{array}{l}\text { Solid oxide fuel } \\
\text { cells, oxygen } \\
\text { sensors and ceramic } \\
\text { membranes }\end{array}$ & $\begin{array}{l}\text { Renewable energy, } \\
\text { chemical industry, water } \\
\text { desalination sectors }\end{array}$ \\
\hline [111-113] & $\begin{array}{l}\text { TiN and } \\
\text { FeN }\end{array}$ & CNTs/graphene & $\begin{array}{l}\text { Excellent electrical } \\
\text { properties }\end{array}$ & $\begin{array}{l}\text { Capacitors, } \\
\text { electronic } \\
\text { conductor in } \\
\text { electronic devices }\end{array}$ & $\begin{array}{l}\text { Electrochemical } \\
\text { industry, power and } \\
\text { electronic sector, } \\
\text { aerospace and } \\
\text { automobile industries }\end{array}$ \\
\hline [114] & Mulite & CNTs/graphene & $\begin{array}{l}\text { High in electric and } \\
\text { optical properties }\end{array}$ & Sensor & $\begin{array}{l}\text { Electronic industry, } \\
\text { aerospace sector and } \\
\text { automobile industry }\end{array}$ \\
\hline
\end{tabular}




\section{Conclusions}

Advanced in the ceramics reinforced with carbon nanostructures (CNTs and graphene) have been thoroughly reviewed. Successes in the purification and dispersions of MWCNTs are somehow satisfactory, however SWCNTs need further research and standards for CNT dispersion are vital for addressing the quality and reliability with confidence. Microwave sintering has potential for producing dense nanocomposites and may eliminate the CNT damage problem associated with the hot-pressing, and by adopting to standard testing methods fracture toughness discrepancies could be reduced. CNTs-reinforced ceramics follow the combined advanced toughening mechanisms of CNT's stretching/uncoiling and the classical fibre pullout theory, as an energy dissipating process. Rough surface and nanopits of MWCNTs explain the strong interface connections with ceramic matrix and the confirmation of the formation of intermediate $\mathrm{Al}_{2} \mathrm{OC}$ or $\mathrm{Al}_{4} \mathrm{C}_{3}$ phases at the interface further strengthens these explanations. Conclusively, problems of reinforcing MWCNTs into ceramics have been solved to some extend; however, the addition of SWCNTs still carries questions. Despite challenges and controversial issues, CNTs have successfully enhanced the toughness and other properties of brittle ceramics and converted them into useful materials for next generation applications.

It is clear that graphene can play an important role as filler in ceramics according to publications. In addition to the exceptional mechanical properties of GNPs which are similar to CNTs, researches have shown that GNPs can be more easily dispersed in ceramic matrix than CNTs which is the key challenge in preparing ceramic composites. Additionally its 2D and flexible microstructure introduced a new toughening mechanism in the ceramic matrix (anchoring around the grain) that could significantly absorb energy against crack propagation and delay the fracture. However, work on graphene ceramic composites is in its early stages and there are still considerable works that need to be done in order to optimise their processing, microstructure and interfacial properties to obtain better multifunctional properties from graphene-ceramic composites.

\section{Acknowledgments}

Iftikhar Ahmad gratefully acknowledges the technical and financial support of Research Center of College of engineer, Deanship of Scientific Research, King Saud University, Riyadh, Kingdom of Saudi Arabia.

\section{Author Contributions}

Iftikhar Ahmad contributed to the carbon nanotube part, Bahareh Yazdani contributed to the graphene part, and Yanqiu Zhu involved in all stages of the article preparation.

\section{Conflicts of Interest}

The authors declare no conflict of interest. 


\section{References}

1. Niihara, K. New design concept of structural ceramics-ceramics nanocomposites. J. Ceram. Soc. Jpn. 1991, 99, 974-982.

2. Osayande, L.; Okoli, O.I. Fracture toughness enhancement for $\mathrm{Al}_{2} \mathrm{O}_{3}$ system: A review. Int. J. Appl. Ceram. Technol. 2008, 5, 313-323.

3. Ohnabe, H.; Masaki, S.; Sasa, T. Potential application of ceramics matrix composites to aero-engine components. Compos. A 1999, 30, 489-496.

4. Llorca, J.; Elices, M.J.; Celemin, A. Toughness and microstructural degradation at high temperature in SiC fiber-reinforced ceramics. Acta Mater. 1998, 46, 2441-2453.

5. Yongqing, F.; Gu, Y.W.; Hejun, D. SiC whisker toughened $\mathrm{Al}_{2} \mathrm{O}_{3}-(\mathrm{Ti}, \mathrm{W}) \mathrm{C}$ ceramic matrix composites. Scr. Mater. 2001, 44, 111.D-116.D.

6. Garcia, E.; Schicker, S.; Bruhn, J.; Janssen, R.; Claussen, N. Processing and mechanical properties of pressureless-sintered niobium- $\mathrm{Al}_{2} \mathrm{O}_{3}$-matrix composites. J. Am. Ceram. Soc. 1998, $81,429-432$.

7. Padture, N.P. Multifunctional composites of ceramics and single-walled carbon nanotubes. Adv. Mater. 2009, 21, 1767-1770.

8. Sheldon, B.W.; Curtin, W.A. Nanoceramics composites tough to test. Nat. Mater. 2004, 3, 505-506.

9. Peigney, A. Tougher ceramics with nanotubes. Nat. Mater. 2003, 2, 15-16.

10. Corral, E.; Bell, N.; Stuecker, J.; Perry, N.; Garay, J.; Barrera, E.V. Engineered nanostructures for multifunctional single-walled carbon nanotube reinforced silicon nitride nanocomposites. J. Am. Ceram. Soc. 2008, 91, 3129-3137.

11. Fan, J.; Zhao, D.; Song, J. Preparation and microstructure of multi-walled carbon nanotubes toughened $\mathrm{Al}_{2} \mathrm{O}_{3}$ composite. J. Am. Ceram. Soc. 2006, 89, 750-753.

12. Yamamoto, G.; Omori, M.; Hashida, T.; Kimura, H. A novel structure for carbon nanotube reinforced $\mathrm{Al}_{2} \mathrm{O}_{3}$ composites with improved mechanical properties. Nanotechnology 2008, 19,315708 .

13. Xia, Z.H.; Lou, J.; Curtin, W.A. A multiscale experiment on the tribological behavior of aligned carbon nanotube/ceramic composites. Scr. Mater. 2008, 58, 223.

14. Wie, T.; Fan, Z.; Wie, F. A new structure for multi-walled carbon nanotubes reinforced $\mathrm{Al}_{2} \mathrm{O}_{3}$ nanocomposite with high strength and toughness. Mater. Lett. 2008, 62, 641-644.

15. Zhan, G.D.; Mukherjee, A. Processing and characterization of nanoceramic composites with interesting structural and functional properties. Rev. Adv. Mater. Sci. 2005, 10, 185-196.

16. Costa, J.; Flacker, A.; Nakashima, M.; Fruett, F.; Zampieri, M.; Longo E. Integration of microfabricated capacitive bridge and thermistor on the alumina substrates. ECS Trans. 2012, 49, 451-458.

17. Martin, C.A.; Lee, G.F.; Fedderly, J.J. Composite Armor System Including a Ceramic-Embedded Heterogeneously Layered Polymeric Matrix. U.S. Patent 8387510 B1, 2013.

18. Baron, B.; Kumar, C.; le Gonidec, G.; Hampshire, S. Comparison of different alumina powders for the aqueous processing and pressureless sintering of $\mathrm{Al}_{2} \mathrm{O}_{3}-\mathrm{SiC}$ nanocomposites. J. Eur. Ceram. Soc. 2002, 22, 1543-1552. 
19. Ipek, M.; Zeytin, S.; Bindal, C. An evaluation of $\mathrm{Al}_{2} \mathrm{O}_{3}-\mathrm{ZrO}_{2}$ composites produced by coprecipitation method. J. Alloys Compd. 2011, 509, 486-489.

20. Wang, K.; Wang, Y.F.; Fan, Z.J.; Yan, J.; Wei, T. Preparation of composites by spark plasma sintering. Mater. Res. Bull. 2011, 46, 315-318.

21. Ramirez, C.; Garzón, L.; Miranzo, P.; Osendi, M.; Ocal, C. Electrical conductivity maps in graphene nanoplatelet/silicon nitride composites using conducting scanning force microscopy. Carbon 2011, 49, 3873-3880.

22. Balazsi, C. Silicon nitride composites with different nanocarbon additives. J. Korean Ceram. Soc. 2012, 49, 352-362.

23. Kvetkova, L.; Duszova, A.; Hvizdos, P.; Dusza, J.; Kun, P.; Balazsi, C. Fracture toughness and toughening mechanisms in graphene platelet reinforced $\mathrm{Si}_{3} \mathrm{~N}_{4}$ composites. Scr. Mater. 2012, 66, $793-796$.

24. Liu, J.; Yan, H.; Reece, M.J.; Jiang, K. Toughening of zirconia/alumina composites by the addition of graphene platelets. J. Eur. Ceram. Soc. 2012, 32, 4185-4193.

25. Walker, L.S.; Marotto, V.R.; Rafiee, M.A.; Koratkar, N.; Corral, E.L. Toughening in graphene ceramic composites. ACS Nano 2011, 5, 3182-3190.

26. Yazdani, B.; Xia, Y.; Ahmad, I.; Zhu, Y. Graphene and carbon nanotube (GNT)-reinforced alumina nanocomposites. J. Eur. Ceram. Soc. 2015, 35, 179-186.

27. Fan, Y.; Wang, L.; Li, J.; Sun, S.; Chen, F.; Chen, L.; Jiang, W. Preparation and electrical properties of graphene nanosheet $/ \mathrm{Al}_{2} \mathrm{O}_{3}$ composites. Carbon 2010, 48, 743-1749.

28. Ebbesen, T.W.; Ajyan, P.M. Large scale synthesis of carbon nanotubes Nature 1992, 358, $220-222$.

29. Hiura, H.; Ebbesen, T.W.; Tanigaki, K. Opening and purification of carbon nanotubes in high yields. Adv. Mater. 1995, 7, 275-276.

30. Tohji, K.; Takashaki, H.; Nishina, Y. Purification procedure for single-walled nanotubes. J. Phys. Chem. 1997, B101, 1974-1978.

31. Ahmad, I.; Islam, M.; Almajid, A.; Yazdani, B.; Zhu, Y.Q. Investigation of yttria-doped $\mathrm{Al}_{2} \mathrm{O}_{3}$ nanocomposites reinforced by multi-walled carbon nanotubes. Ceram. Int. 2014, 40, 9327-9335.

32. Ahmad, I.; Kennedy, A.; Zhu, Y.Q. Carbon nanotubes reinforced $\mathrm{Al}_{2} \mathrm{O}_{3}$ nanocomposites: Mechanical properties and interfacial investigations. J. Comput. Sci. Technol. 2010, 70, 1199-1206.

33. Zhang, S.C.; William, G.; Hilmas, G.E.; Edward, J.Y. Pressureless sintering of carbon nanotube- $\mathrm{Al}_{2} \mathrm{O}_{3}$ composites. J. Eur. Ceram. Soc. 2010, 30, 1373-1380.

34. Sarkar, S.; Das, P.K. Microstructure and physic-mechanical properties of pressure-less sintered multi-walled carbon nanotubes $/ \mathrm{Al}_{2} \mathrm{O}_{3}$ nanocomposites. Ceram. Int. 2012, 38, 423-432.

35. Michalek, M.; Lkova, M.; Sedla, J.; Galusek, D. $\mathrm{Al}_{2} \mathrm{O}_{3} / \mathrm{MWCNTs}$ composites by aqueous slip casting and pressureless sintering. Ceram. Int. 2013, L39, 6543-6550.

36. Wang, J.; Kou, H.; Liu, X.; Pan, Y.; Guo, J. Reinforcement of mullite matrix with multi-walled carbon nanotubes. Ceram. Int. 2007, 33, 719-722.

37. Pasupuleti, S.; Peddetti, R.; Halloran, J.P. Toughening behavior in a carbon nanotube reinforced silicon nitride composite. Mater. Sci. Eng. 2008, A491, 224-229.

38. Tian, W.; Kan, Y.; Wang, P. Effect of carbon nanotubes on the properties of $\mathrm{ZrB}_{2}-\mathrm{SiC}$ ceramics. Mater. Sci. Eng. 2008, 487, 568-573. 
39. Huang, Q.; Gao, L.; Sun, J. Effect of adding carbon nanotubes on microstructure, phase transformation and mechanical properties of $\mathrm{BaTiO}_{3}$ ceramics. J. Am. Ceram. Soc. 2005, 88, 3515-3518.

40. Kumari, L.; Zhang, T.; Du, G.H.; Li, W.Z.; Wang, Q.W.; Datye, A.; Wu, K.H. Synthesis, microstructure and electrical conductivity of carbon nanotube-alumina nanocomposites. Ceram. Int. 2009, 35, 1775-1781.

41. Echeberria, J.; Rodríguez, N.; Bocanegra-Bernal, M.H. Hard and tough carbon nanotube-reinforced zirconia-toughened $\mathrm{Al}_{2} \mathrm{O}_{3}$ composites prepared by spark plasma sintering. Carbon 2012, 50, $706-717$.

42. Kim, S.W.; Chung, W.S.; Sohn, K.S.; Son, C.Y.; Lee, S. Improvement of flexure strength and fracture toughness in alumina matrix composites reinforced with carbon nanotubes. Mater. Sci. Eng. 2009, A517, 293-299.

43. Bakhsh, N.; Khalid, F.A.; Hakeem, A.S. Effect of sintering temperature on densification and mechanical properties of pressureless sintered $\mathrm{CNT}-\mathrm{Al}_{2} \mathrm{O}_{3}$ nanocomposites. Mater. Sci. Eng. 2014, 60, 012059.

44. Li, T. Improving the antistatic ability of polypropylene fibers by inner antistatic agent filled with carbon nanotubes. Comput. Sci. Tech. 2004, 64, 2089-2096.

45. Hanzel, O.; Sedlácek, J.; Sajgalík, P. New approach for distribution of carbon nanotubes in $\mathrm{Al}_{2} \mathrm{O}_{3}$ matrix. J. Eur. Ceram. Soc. 2014, 34, 1845-1851.

46. Michalek, M.; lkova, M.; Sedla, J.; Galusek, D. Mechanical properties and electrical conductivity of $\mathrm{Al}_{2} \mathrm{O}_{3} / \mathrm{MWCNT}$ and $\mathrm{Al}_{2} \mathrm{O}_{3}$ /zirconia/MWCNT composites. Ceram. Int. 2014, 40, 1289-1295.

47. Poyato, R.; Gallardo-López, A.; Gutiérrez-Mora, F.; Morales-Rodríguez, A.; Muñoz, A.; Domínguez-Rodríguezb, A. Effect of high SWNT content on the room temperature mechanicalproperties of fully dense 3YTZP/SWNT composites. J. Eur. Ceram. Soc. 2014, 34, 1571-1579.

48. Kyotani, T.; Tsai, L.F.; Tomita, A. Preparation of ultrafine carbon tubes in nanochannels of an anodic aluminum oxide film. Chem. Mater. 1996, 8, 2109-2113.

49. Sui, Y.C.; Acosta, D.R.; Cui, B.Z. Structure, thermal stability, and deformation of multibranched carbon nanotubes synthesized by CVD in the AAO template. J. Phys. Chem. 2001, B105, 1523-1527.

50. Bae, E.J.; Choi, W.B.; Park, G.S.; Song, S. Selective growth of carbon nanotubes on pre-patterned porous anodic aluminum oxide. Adv. Mater. 2002, 14, 277-279.

51. Parhama, H.; Bates, S.; Xia, Y.; Zhu, Y. A highly efficient and versatile carbon nanotube/ceramic composite filter. Carbon 2013, 54, 215-223.

52. Parhama, H.; Kennedy, A.; Zhu, Y. Preparation of porous $\mathrm{Al}_{2} \mathrm{O}_{3}$ - Carbon nanotube composites via direct growth of carbon nanotubes. J. Comput. Sci. Technol. 2011, 71, 1739-1745.

53. Sun, J.; Gao, L. Development of a dispersion process for carbon nanotubes in ceramic matrix by hetero-coagulation. Carbon 2003, 41, 1063-1068.

54. Chan, B.; Seung, I. Fabrication of CNT-reinforced $\mathrm{Al}_{2} \mathrm{O}_{3}$ matrix nanocomposites by sol-gel. Mater. Sci. Eng. 2005, 395, 124-128.

55. Sun, J.; Gao, L. Reinforcement of $\mathrm{Al}_{2} \mathrm{O}_{3}$ matrix with multi-walled CNT. Ceram. Int. 2004, 893-896. 
56. Gao, L.; Jiang, L.; Sun, J. Carbon nanotube-ceramic composites. J. Electroceram. 2006, 17, 51-55.

57. Coble, R.L. Diffusion Models for hot pressing with surface energy and pressure effects as driving forces. J. Appl. Phys. 1970, 41, 4798-4808.

58. Legorreta, G.; Estournes, C.; Peigney, A.; Weibel, A.; Flahaut, E.; Laurent, C. Spark-plasma-sintering of double-walled carbon nanotube-magnesia nanocomposites. Scr. Mater. 2009, 60, 741-744.

59. Ahmad, I.; Dar, M.A. Structure and properties of $\mathrm{Y}_{2} \mathrm{O}_{3}$-doped $\mathrm{Al}_{2} \mathrm{O}_{3}-\mathrm{MWCNT}$ nanocomposites prepared by PL-sintering and hot-pressing. J. Mater. Eng. Perform. 2014, 23, 2110-2119

60. Ghobadi, H.; Ali, N.; Ebadzade, T.; Sadeghian, Z.; Barzegar-Bafrooei, H. Improving CNT distribution and mechanical properties of MWCNT reinforced $\mathrm{Al}_{2} \mathrm{O}_{3}$ matrix. Mater. Sci. Eng. 2014, A617, 110-114.

61. Tatami, J.; Katashima, T.; Komeya, K.; Meguro, T.; Wakihara, T. Electrically conductive CNT-dispersed silicon nitride ceramics. J. Am. Ceram. Soc. 2005, 88, 2889-2893.

62. Katz, J.D.; Blake, R.D. Microwave sintering of multiple alumina and composite components. J. Am. Ceram. Soc. 1991, 70, 1304.

63. Sheppard, L.M. Firing technology heats up for the 90s. J. Am. Ceram. Soc. 1988, 67, 1656.

64. De, A.; Ahmad, I.; Whitney, E.D.; Clark, D.E. Microwaves theory and applications. Mater. Process. 1991, 21, 329-339.

65. Fujitsu, S.; Ikegami, M.; Hyashi, T. Sintering of partially stabilized zirconia by microwave heating using $\mathrm{ZnO}-\mathrm{MnO}_{2}-\mathrm{Al}_{2} \mathrm{O}_{3}$ plates in a domestic microwave oven. J. Am. Ceram. Soc. 2000, 83, 2085-2087.

66. Ahmad, I.; Cao, H.; Chen, H.; Zhao, H.; Kennedy, A.; Zhu, Y. Carbon nanotube toughened aluminium oxide nanocomposites. J. Eur. Ceram. Soc. 2009, 30, 865-873.

67. Valecillos, M.C.; Hirota, M.; Brite, M.E.; Hirao, K. Sintering of alumina by $2.45 \mathrm{GHz}$ microwave heating. J. Eur. Ceram. Soc. 2004, 24, 387-391.

68. Thostenson, P.G.; Karandikar, T.W. Fabrication and characterization of reaction bonded silicon carbide/carbon nanotube composites. J. Appl. Phys. 2005, 38, 3962-3965.

69. Wang, Y.; Voronin, G.A.; Zerda, T.W.; Winiarski, A. SiC-CNT nanocomposites: High pressure reaction synthesis and characterization. J. Phys. Condens. Matter. 2006, 18, 275-282.

70. Kristen, H.B.; Gary, L.M.; Dinesh, K.A. Microwave sintering of alumina at 2.45 GHz. J. Am. Ceram. Soc. 2003, 86, 1307-1312.

71. Lopez, A. Hardness and flexural strength of single-walled carbon nanotubes $/ \mathrm{Al}_{2} \mathrm{O}_{3}$ composites. J. Mater. Sci. 2014, 49, 7116-7123.

72. Zaman, A.C.; Kaya, F.; Kaya, C. $\mathrm{OH}$ and $\mathrm{COOH}$ functionalized single walled carbon nanotubes-reinforced alumina ceramic nanocomposites. Ceram. Int. 2012, 38, 1287-1293.

73. Estili, M.; Kawasaki, A.; Sakka, Y. Highly concentrated 3D macrostructure of individual carbon nanotubes in a ceramic environment. Adv. Mater. 2012, 24, 4322-4326.

74. Martinlli, J.R.; Sene, F.F. Electrical resistivity of ceramic-metal composite materials: Application in crucibles for induction furnaces. Ceram. Int. 2000, 26, 325-335.

75. Puchy, V.; Hvizdos, P.; Dusza, J.; Kovac, F.; Inam, F.; Reece, M.J. Wear resistance of $\mathrm{Al}_{2} \mathrm{O}_{3}-\mathrm{CNT}$ ceramic nanocomposites at room and high temperature. Ceram. Int. 2013, 39, 5821-5826. 
76. Lee, K.; Mo, C.B.; Park, S.B.; Hong, S.H. Mechanical and electrical properties of multiwalled CNT-alumina nanocomposites prepared by a sequential two-step processing of ultrasonic spray pyrolysis and spark plasma sintering. J. Am. Cream. Soc. 2011, 94, 3774-3779.

77. Thomson, K.E.; Jiang, D.; Yao, W.; Ritchie, R.O.; Mukherjee, A.K. Characterization and mechanical testing of alumina-based nanocomposites reinforced with niobium and/or carbon nanotubes fabricated by spark plasma sintering. Acta Mater. 2012, 60, 622-632.

78. Ahmad, I.; Kennedy, A.; Zhu, Y. Wear resistance properties of multi-walled carbon nanotubes reinforced $\mathrm{Al}_{2} \mathrm{O}_{3}$ nanocomposite. Wear 2010, 269, 71-78.

79. Zhan, G.D.; Mukherjee, A.K. Carbon nanotube reinforced alumina-based ceramics with novel mechanical, electrical, and thermal properties. Int. J. Appl. Ceram. Technol. 2004, 1, 161-171.

80. Sarkar, S.; Das, P.K. Effect of sintering temperature and nanotube concentration on microstructure and properties of carbon nanotube/alumina nanocomposites. Ceram. Int. 2014, 40, 7449-7458.

81. Bi, S.; Su, X.; Hou, G.; Liu, C.; Song, W.L.; Cao, M.S. Electrical conductivity and microwave absorption of shortened multi-walled carbon nanotube/alumina ceramic composites. Ceram. Int. 2013, 39, 5979-5983.

82. Bakshi, S.R.; Balani, K.; Agarwal, A. Thermal conductivity of plasma-sprayed aluminum oxide-Multiwalled carbon nanotube composites. J. Am. Cream. Soc. 2008, 91, 942-947.

83. Laurent, C.; Peigney, A.; Rousset, A. Carbon nanotubes-Fe- $\mathrm{Al}_{2} \mathrm{O}_{3}$ nanocomposites. Part II: Microstructure and mechanical properties of the hot-pressed composites. J. Eur. Ceram. Soc. 1998, 18, 2005-2013.

84. Siegel, R.W.; Chang, S.K.; Ajayan, P.M. Mechanical behaviour of polymer and ceramic matrix nanocomposite. Scr. Mater. 2001, 44, 2061-2064.

85. Hoagland, R.G. A treatment of inelastic deformation around a crack tip due to micro cracking. J. Am. Ceram. Soc. 1980, 63, 404-410.

86. Kawamura, H.; Yamamoto, S. Improvement of Diesel Engine Startability by Ceramic Glow Plug Start System; Society of Automotive Engineers: New York, NY, USA; 1983.

87. Zheng, G.; Sano, H.; Cheng, H.M. A TEM study of the microstructure of carbon fiber/polycarbosilane-derived SiC composites. Carbon 1999, 37, 2057-2062.

88. Estili, M. The homogeneous dispersion of surfactantless, slightly disordered, crystalline, multiwalled carbon nanotubes in $\alpha$-alumina ceramics for structural reinforcement. Acta Mater. 2008, 56, 4070-4079.

89. Knieke, C.; Berger, A.; Voigt, M.; Taylor, R.N.K.; Röhrl, J.; Peukert, W. Scalable production of graphene sheets by mechanical delamination. Carbon 2010, 48, 3196-3204.

90. Hummers, J.; William, S.; Offeman, R.E. Preparation of graphitic oxide. J. Am. Chem. Soc. 1958, 80, 1339-1339.

91. Inam, F.; Yan, H.; Reece, M.J.; Peijs, T. Dimethylformamide: an effective dispersant for making ceramic-carbon nanotube composites. Nanotechnology 2008, 19, 195710.

92. Balázsi, C.; Wéber, F.; Arató, P.; Fényi, B.; Hegman, N.; Kónya, Z.; Kiricsi, I.; Vértesy, Z.; Biró, L.P. Development of CNT-silicon nitrides with improved mechanical and electrical properties. Adv. Sci. Technol. 2006, 45, 1723-1728. 
93. Milsom, B.; Viola, G.; Gao, Z.; Inam, F.; Peijs, T.; Reece, M.J. The effect of carbon nanotubes on the sintering behaviour of zirconia. J. Eur. Ceram. Soc. 2012, 32, 4149-4156.

94. Guo, S.; Sivakumar, R.; Kitazawa, H.; Kagawa, Y. Electrical properties of silica-based nanocomposites with multiwall carbon nanotubes. J. Am. Ceram. Soc. 2007, 90, 1667-1670.

95. Liu, J.; Yan, H.; Jiang, K. Mechanical properties of graphene platelet-reinforced alumina ceramic composites. Ceram. Int. 2013, 39, 6215-6221.

96. Ramirez, C.; Osendi, M.I. Characterization of graphene nanoplatelets- $\mathrm{Si}_{3} \mathrm{~N}_{4}$ composites by Raman spectroscopy. J. Eur. Ceram. Soc. 2013, 33, 471-477.

97. Kvetková, L.; Duszová, A.; Kašiarová, M.; Orčáková, F.; Dusza, J.; Balázsi, C. Influence of processing on fracture toughness of $\mathrm{Si}_{3} \mathrm{~N}_{4}+$ graphene platelet composites. J. Eur. Ceram. Soc. 2013, 33, 2299-2304.

98. Inam, F.; Vo, T.; Bhat, B.R. Structural stability studies of graphene in sintered ceramic nanocomposites. Ceram. Int. 2014, 40, 16227-16233.

99. Rutkowski, P.; Stobierski, L.; Górny, G. Thermal stability and conductivity of hotpressed $\mathrm{Si}_{3} \mathrm{~N}_{4}$-graphene composites. J. Therm. Anal. Calorim. 2014, 116, 321-328.

100. Tapaszto, O.; Kun, P.; Weber, F.; Gergely, G.; Balazsi, K.; Pfeifer, J.; Arato, P.; Kidari, A.; Hampshire, S.; Balazsi, C. Silicon nitride based nanocomposites produced by two different sintering methods. Ceram. Int. 2011, 37, 3457-3461.

101. Evans, A.G. Perspective on the development of high-toughness ceramics. J. Am. Ceram. Soc. 1990, 73, 187-206.

102. Ritchie, R.O. The quest for stronger tougher materials. Science 2008, 320, 448-452.

103. Curtin, W.A.; Sheldon, B.W. CNT-reinforced ceramics and metals. Mater. Today 2004, 7, 44-49.

104. Kramer, P.; White, K. Effect of sintering parameters and composition on the resistivity of a cermet used as an electrical feed through. Ceram. Eng. Sci. Proc. 1982, 3, 512-518.

105. Tajima, Y. Development of high performance silicon nitride ceramics and their applications. Mater. Res. Soc. Symp. Proc. 1993, 287, 98-201.

106. Komeya, H.K. Development of ceramic antifriction bearing. JSAE Rev. 1986, 7, 72-79.

107. Huang, Q.; Gao, L. Manufacture and electrical properties of multiwalled carbon nanotube/BaTiO 3 nanocomposite ceramics. J. Mater. Chem. 2004, 14, 2536-2541.

108. Lee, S.Y.; Kim, H.; McIntyre, P.C.; Saraswat, K.C.; Byun, J.S. Atomic layer deposition of $\mathrm{ZrO}_{2}$ on W for metal-insulator-metal capacitor application. Appl. Phys. Lett. 2003, 823, 2874-2876.

109. Dusza, J.; Tomasek, K.; Blugan, G.; Kuebler, J. Microstructure and properties of carbon nanotube/zirconia composite. J. Eur. Ceram. Soc. 2008, 28, 1023-1027.

110. Patsalas, P.; Logothetidis, S. Optical, electronic, and transport properties of nanocrystalline titanium nitride thin films. J. Appl. Phys. 2001, 90, 4725-4734.

111. Carmalt, C.J.; Whaley, S.R.; Lall, P.S.; Cowley, A.H.; Jones, R.A. Titanium (IV) azido and imido complexes as potential precursors to titanium nitride. J. Chem. Soc. Dalton Trans. 1998, 1998, 553-558.

112. Janes, R.A.; Aldissi, M.; Kaner, R.B. Controlling surface area of titanium nitride using metathesis reactions. Chem. Mater. 2003, 15, 4431-4435.

113. Kim, S.; Kumta, P.N. Hydrazide sol-gel synthesis of nanostructured titanium nitride: Precursor chemistry and phase evolution. J. Mater. Chem. 2003, 13, 2028-2035. 
114. Cao, M.S.; Wang, R.G.; Fang, X.Y.; Cui, Z.X.; Chang, T.J.; Yang, H.J. Preparing $\gamma^{\prime}-F e 4 N$ ultrafine powder by twice-nitriding method. Powder Technol. 2001, 115, 96-98.

(C) 2015 by the authors; licensee MDPI, Basel, Switzerland. This article is an open access article distributed under the terms and conditions of the Creative Commons Attribution license (http://creativecommons.org/licenses/by/4.0/). 